\title{
3D Printing as a Promising Tool in Personalized Medicine
}

\author{
Vanessa Marcia $\operatorname{Vaz}^{1}$ and Lalit Kumar,
}

Received 4 September 2020; accepted 18 December 2020; published online 17 January 2021

\begin{abstract}
Personalized medicine has the potential to revolutionize the healthcare sector, its goal being to tailor medication to a particular individual by taking into consideration the physiology, drug response, and genetic profile of that individual. There are many technologies emerging to cause this paradigm shift from the conventional "one size fits all" to personalized medicine, the major one being three-dimensional (3D) printing. 3D printing involves the establishment of a three-dimensional object, in a layer upon layer manner using various computer software. 3D printing can be used to construct a wide variety of pharmaceutical dosage forms varying in shape, release profile, and drug combination. The major technological platforms of 3D printing researched on in the pharmaceutical sector include inkjet printing, binder jetting, fused filament fabrication, selective laser sintering, stereolithography, and pressure-assisted microsyringe. A possible future application of this technology could be in a clinical setting, where prescriptions could be dispensed based on individual needs. This manuscript points out the various $3 \mathrm{D}$ printing technologies and their applications in research for fabricating pharmaceutical products, along with their pros and cons. It also presents its potential in personalized medicine by individualizing the dose, release profiles, and incorporating multiple drugs in a polypill. An insight on how it tends to various populations is also provided. An approach of how it can be used in a clinical setting is also highlighted. Also, various challenges faced are pointed out, which must be overcome for the success of this technology in personalized medicine.
\end{abstract}

KEY WORDS: 3D printing; personalized medicine; dosage forms; polypill; clinical practice.

\section{INTRODUCTION}

The current scenario of medical treatment is centered on the paradigm "one size fits all" where most patients receive same drugs at the same doses and frequencies as others (1). It came to light that this theory of "one size fits all" does not hold up in all treatments. Administration of the same active ingredient at the same dose to different individuals has shown varied responses. The response might be exaggerated and linked with adverse drug reactions (ADRs) or too weak, with insufficient or no pharmacological effects. Both these situations can be succeeded by added patient complications (2). This leads to the initiation of personalized medicines where medications are tailored to patients or designed more particularly for them as part of a group of genetically, physiologically or pathologically similar patients (3). With a mantra of "one size does not fit all", its goal is to dispense the best drug at the best dose, for the precise indication of the patient, at the correct time (1). Personalized medicine

\footnotetext{
${ }^{1}$ Department of Pharmaceutics, Manipal College of Pharmaceutical Sciences, Manipal Academy of Higher Education, Manipal, Udupi, Karnataka 576 104, India.

${ }^{2}$ To whom correspondence should be addressed. (e-mail: lalit.kumar@manipal.edu)
}

promises are more precise medications. These are more safe and efficacious, improve patient compliance, and are costeffective (4).

Three-dimensional printing, also called 3D printing or additive manufacturing, involves the deposition of material in a layer upon layer manner to gradually construct a solid model. It uses a computer-aided design (CAD) software which transfers the necessary signals to a 3D printer, which then converts the computerized digital model into twodimensional (2D) sections, which generates solid layers to build up the required objects (5). It has been widely used in various industries, from automobile and aerospace to biomedical and pharmaceutical industry. It is also being used in the construction of buildings, entertainment, fashion industry, art, and jewelry. In the pharmaceutical industry, it has been employed for the fabrication of various pharmaceutical products like controlled release tablets, polypills, orodispersible films, gastrofloating tablets, self-emulsifying drug delivery systems, microneedles, and transdermal patches (6). The various printing technologies include inkjet printing method, binder jet printing method, fused deposition method, selective laser sintering, stereolithography, and pressureassisted microsyringe (7).

With 3D printing, pharmaceuticals have the potential to bring in a major change in the design, use, and manufacture 
of different pharmaceutical products. Conventional manufacturing processes, although cost-effective, might call for rigorous labor and can be time-consuming when it comes to large-scale production. In conventional manufacturing processes, also, the doses cannot be manipulated easily according to the patient needs. 3D printing can transform healthcare through personalized medicine, thus improving patient compliance by tailoring the medication to the patient. This can be achieved through on-demand manufacturing in clinical settings to offer the best medical care (8).

There is a considerable amount of literature review on $3 \mathrm{D}$ printing and its application in drug delivery. However, there are only limited number of articles which explain the various technologies involved in $3 \mathrm{D}$ printing and their applications in pharmaceuticals, along with their use in personalized medicine and their ability to tend to various populations.

\section{HISTORY OF 3D PRINTING}

The earliest research in $3 \mathrm{D}$ printing dates back to the late 1970s, which saw various patents regarding the techniques of computer-aided additive manufacture, employing different platforms (9). In the mid-1980s, Charles (Chuck) Hull, also regarded as the pioneer of this technology, invented and patented stereolithography (SLA), which is one of the major technologies in 3D printing. This process involved resins which were polymerized using UV light to obtain the desired object. These SLA printers were then commercialized by 3D Systems, which was founded by Hull $(10,11)$.

In 1986, Carl Deckard, a university student of Texas, developed another technology known as Selective laser sintering which employed laser to fuse powder together. This was followed by another patent for fused deposition modeling in 1989 by Scott and Lisa Crump at the company Stratasys. This process involved heating and extruding plastic or metal using nozzle. Later in 1989, Emanuel Sachs and his associates at MIT developed "three-dimensional printing techniques" which employed binding solution extruded on a powder bed by modifying the inkjet printer. This later came to be known as the "binder jetting" method. Hans Langer in 1989 focused on direct metal laser sintering which utilized laser, to produce $3 \mathrm{D}$ objects using computer models $(10,12)$.

Various initiatives were carried out so that people could obtain the low cost and non-proprietary printers. Replicating rapid prototyping (Rep Rap) project was founded and carried out by Andrew Bowyer of the University of Bath which involved developing 3D printers that produce most of its own components, which then grew widely with several collaborations (9).

Since its invention and the use of 3D printing technology has expanded to various fields. Initially, clinical applications in healthcare were for surgical planning and guidance and to produce implants. Implants loaded with active pharmaceutical ingredients were also developed with a good potential for personalization (13). 3D printing was also used for clinical educational purposes (14). 3D printing has now entered the pharmaceutical sector, where it has been used to develop various dosage forms. In 2015, the very first 3D printed drug, Spritam (Levetiracetam), a prescription drug for epilepsy developed by Aprecia Pharmaceuticals was approved by the
FDA. This was manufactured using the binder jet printing method and is capable of rapid oral dissolution because of its highly porous structure (15).

\section{D PRINTING TECHNOLOGIES USED IN PHARMACEUTICAL DEVELOPMENT}

\section{Inkjet Printing Method}

In general, inkjet printing describes systems which use pattern generating devices to digitally control and place small liquid drops on a substrate. In pharmaceuticals, appropriate mixtures of drug, along with suitable excipients (known as ink) are deposited as small drops in a layer wise fashion on a suitable substrate. Continuous inkjet printing (CIJ) and drop on demand (DoD) are the two main inkjet printing platforms $(16,17)$.

\section{Continuous Inkjet Printer}

As the name suggests, continuous inkjet printers eject stream of liquid droplets on a substrate continuously, even when the droplets are not necessary. Here, a pressure wave is generated into the ink stream, which breaks up the ink into uniform sized droplets by means of vibration of the nozzle and then ejects the droplets out of the nozzle. Since it ejects droplets continuously, this technology leads to the wastage of ink. The advantages of this printing technology include high-speed continuous droplet generation, due to which the nozzle does not get clogged easily. Disadvantages include low-resolution and expensive maintenance (18).

\section{Drop-on-Demand Inkjet Printer}

In these printers, drops of liquid are ejected from the printhead due to a trigger signal, only when it is necessary and the drops are deposited onto a substrate. This type of printer typically contains many nozzles (100-1000, but specialized printheads compose of only one). Contrasting the continuous inkjet printer where ejection of droplets is due to the external pressure, drop-on-demand inkjet printers have the drops kinetic energy derived from sources close to each nozzle and located within the printhead (19). This technology is relatively simple, offers high precision and is low cost. It has the potential to deposit small drops of controllable sizes and also produces them with good placement accuracy. It also minimizes the wastage of drugs. Hence, it is favored over continuous inkjet printing for printing applications $(20,21)$.

Drop-on-demand inkjet printer can be further classified, based on the type of printhead, into thermal inkjet and piezoelectric inkjet printer. These can also be classified into drop-on-drop or drop-on-solid on the basis of the substrate on which the printhead deposits the drops (22).

\section{Thermal Inkjet Printer (TIJ)}

Here, thermal energy is the trigger mechanism used to discharge droplets, which then exit the nozzle. The printheads have resistors embedded in them which are in immediate exposure with the fluid (ink) and which upon induction of 
electric current produce heat. This heat then results in the formation of a bubble within the volatile fluid, which then expands and ejects a small volume of fluid out of the nozzle forming a droplet (Fig. 1a). The main limitation of this technique is the use of high temperatures $\left(200-300^{\circ} \mathrm{C}\right)$ of the resistor, which might lead to the degradation of thermo labile active ingredients $(18,23)$.

\section{Piezoelectric inkjet printer (PIJ)}

This technology composes of a piezoelectric element or actuator which changes its shape in response to an electric voltage. This generates a pressure, which leads to the fluid (ink) being ejected out of the nozzle. After the element gets back to its actual shape, the nozzle is reloaded with the fluid and is ready to be activated again $(21,24)$ (Fig. 1b). The main advantages of this technique include its operability at room temperatures using less volatile and more biocompatible fluids (23).

Another interesting technology called "valve jet" or "electromagnetic" printing was used in pharmaceutical printing, which was based on miniature solenoid valves. This is advantageous due to its robustness and larger orifice sizes compared with thermal inkjet printer (TIJ) or piezoelectric inkjet printer (PIJ) and would help in printing coarser suspensions $(25,26)$.

A glass inkjet tool was developed to eject droplets at high frequencies. It would widely suit pharmaceutical applications as glass being inert will not react with any of the materials used (27).

The inkjet technology can be taken further by combining it with UV photo-initiation. UV curing has been used to harden materials rapidly on demand in the inkjet printing industry. The ink used here contains cross-linking functional groups which get triggered by light and a photo-initiator is often used to promote this process (28).

\section{Pharmaceutical Applications of Inkjet Printing}

One of the main applications of inkjet printing in pharmaceuticals is in the preparation of orodispersible film
(ODF) formulations. They are single sheets or multilayered, made up of appropriate materials having drugs loaded on to them, which liberate the drug rapidly in the mouth to form a solution or suspension in the saliva without chewing or water consumption (29). Thabet et al. used PIJ printing to print enalapril maleate onto hydroxy propyl cellulose-based ODFs which were either drug free or contained hydrochlorothiazide. Water- or methanol-based inks were used for this purpose. The doses of enalapril and hydrochlorothiazide could be adjusted in enalapril on hydrochlorothiazide films to obtain various fixed dose combinations (30). TIJ was used to develop ODFs of propranolol hydrochloride in a mixture of water and glycerol on three different edible substrates, i.e., rice paper, coated rice paper, and icing sheet. Saccharin was used as a sweetener to improve palatability, which was included using a casting knife (31). A novel approach of dosing two drugs simultaneously and independently on ODFs using TIJ printer was discussed by modifying a commercial TIJ printer. T3 (liothyronine sodium) and T4 (levothyroxine sodium) were printed on hydroxypropyl methyl cellulose substrates and ink solutions were prepared in mixtures of ethanol, DMSO, and propylene glycol (PG) (32).

Mucoadhesive buccal films were also developed using TIJ in combination with fused deposition modeling (FDM). Here, ibuprofen ink was deposited on HPMC films prepared by FDM technology (33). Another oromucosal dosage form was developed using PIJ, where lidocaine hydrochloride was printed on electrospun gelatin substrates with or without piroxicam (34). Hence, the combination of two technologies to develop pharmaceuticals was demonstrated to be effective. Most of these films used for oral delivery face the disadvantage of limited ink and, hence, drug loading efficiency. To overcome this, edible solid foams were developed which were porous and appropriate for inkjet printing of higher amounts of ink (35). Apart from the deposition of small molecules, there has been research in printing biologics on a suitable substrate using inkjet printer for buccal delivery $(36,37)$.

Inkjet technology has also found its usage in transdermal delivery. Films for transdermal delivery were developed by PIJ technology which were used to load ink formulations of indomethacin in ethanol on polythene films (38). Inkjet

a

b

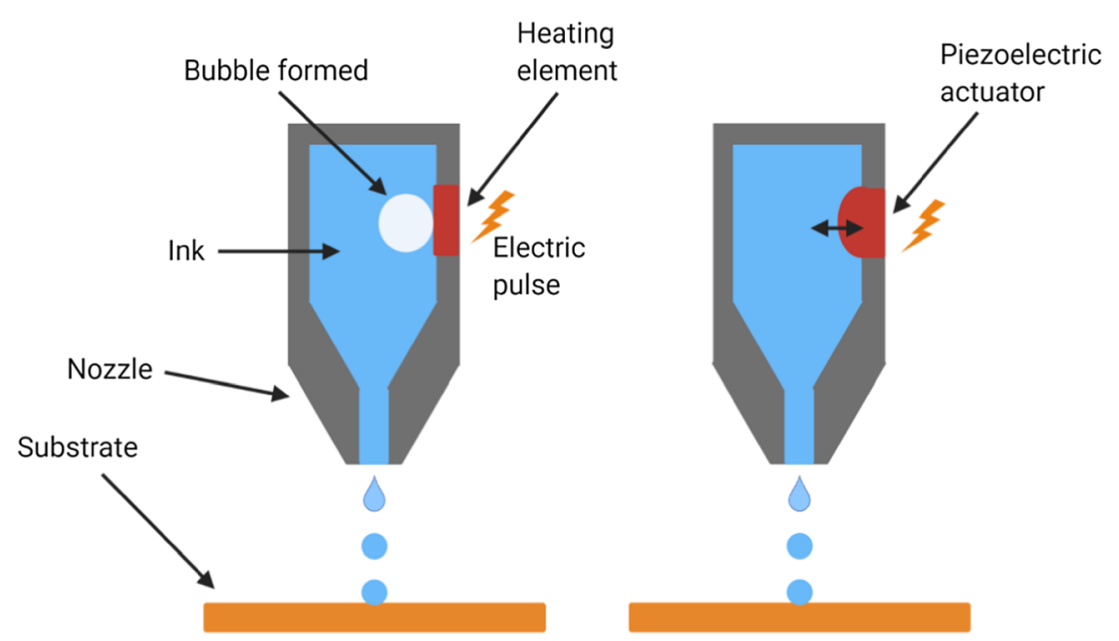

Fig. 1. Schematic of inkjet printhead. a Thermal. b Piezoelectric 
printing has also been used to coat microneedles for transdermal delivery (39-41).

Dropwise additive manufacturing of pharmaceutical products (DAMPP) which uses drop-on-demand technology has been developed to manufacture various dosage forms (20). Using this technology, self-emulsifying drug delivery systems (SEDDS) have been developed to increase the solubility of drugs. Icten et al. developed a formulation using DAMPP by placing a film of a self-emulsifying mixture on a tablet and polymer-based films (42).

Apart from these formulations, tablets of carvedilol and ropinirole have been prepared by using inkjet with photoinitiation $(28,43)$. Also, solvent inkjet printing was used to prepare tablets of thiamine hydrochloride (44). Other formulations developed using inkjet technology were aerogel microspheres for pulmonary delivery (45) and drug-loaded mesoporous silica nanoparticles (46).

\section{Binder Jet Printing}

Binder jet printing, also known as drop-on-powder method is an application of inkjet printing technology. The printhead of a binder jet printer can either be thermal or piezoelectric. It composes of a powder bed which is fused in a layer wise fashion. A printer nozzle which contains the binder (and/or drug) fluid is programmed to jet the liquid onto the loose powder bed by moving along an $x$-y-axis. The powder is in turn moistened by the liquid drops which lead to hardening and solidification of the layer. The powder solidification occurs either by forming binder bridges or by the dissolution and re-crystallization of particles. The fabrication platform then moves downwards across the $z$-axis, and the powder delivery platform moves up. A roller then moves a powder layer from the bed to the top of the formerly bound layer. This procedure is repeated successively and the $3 \mathrm{D}$ object is constructed (Fig. 2). The object is then procured from the powder bed and the unattached powder removed. Thermal sintering is often used to remove any residual volatile solvent. FDA approved Spritam was developed using the zip dose technology, which is based on binder jetting (15). Another technique based on binder jetting is the TheriForm method which is a novel microfabrication process used to construct dosage forms layer by layer, one layer at a time (47).

\section{Pharmaceutical Applications of Binder Jet Printing}

There has been a lot of research on the applications of binder jetting for the fabrication of tablets. The type and concentration of excipients used in the tablet manufacture process by binder jetting have a great impact on the tablet characteristics. It was demonstrated that filling agents having high water solubility, moistening agent having high water content and binders with high viscosity in solution can enhance the hardness and binding strength of the tablets and extend their disintegration time (48). Another study which demonstrated hydroxy propyl cellulose as a potential binder, concluded that the tablet friability vastly depended on the particle size of the binder used (49). Another study investigated the use of linear and 4-arm star polyvinyl pyrrolidone as the binder. They concluded that the compressive strength of a tablet depended on the weight percentage of polymer in the binder. Since 4-arm star polymers had lower viscosities compared with the linear analogues, they were jettable at higher concentrations, producing stronger tablets.

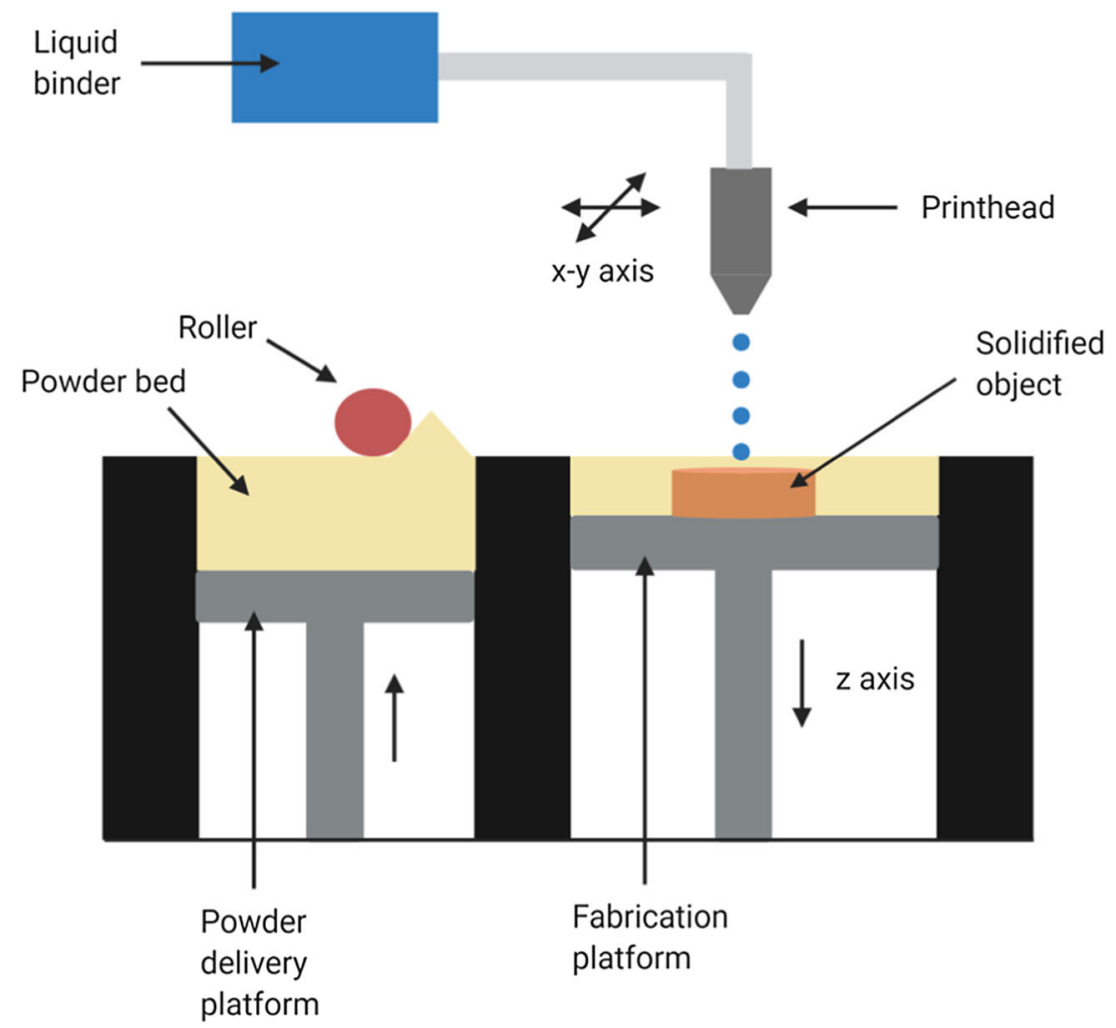

Fig. 2. Schematic of binder jet printer 
Also, the inclusion of acetaminophen in the tablets showed adequate physical properties at $5-50 \%$ concentration in each tablet (50).

Tablets of various APIs with different shapes and release profiles have been developed using binder jetting. Tablets of chlorpheniramine using binder solutions of Eudragit E-100 and Eudragit RLPO were developed, using ethanol and acetone as the solvents, respectively. The tablets were printed with six layers of placebo in the bottom, followed by eight layers comprising of the active ingredient, which was then followed by six more placebo layers on top (51). Another study developed dosage forms of captopril using the TheriForm process, using mannitol as the bulk excipient along with maltitol, maltodextrin or polyvinyl pyrrolidone as powder additives (47). Apart from that, tablets of pseudoephedrine (52), acetaminophen (53), 5-fluorouracil (54), and amitriptyline hydrochloride (55) were developed using binder jetting.

\section{Fused deposition modeling (FDM)}

Fused deposition modeling (FDM) or fused filament fabrication is the most extensively used $3 \mathrm{D}$ printing technique. Thermoplastic drug-loaded polymeric filaments, which after developing, are fed into the printer, where they are melted at a specific temperature and extruded through the nozzle. The printhead moves in a rastor platform and the extruded filament is unloaded on the printer platform, creating the first layer of the object. Successive layers are then deposited upon lowering the platform each time to allow room for the subsequent layer. The filaments cool down and attach to the preceding layer. This procedure is repeated to produce the final 3D article (Fig. 3). The printhead temperature can be manipulated in most printers allowing the use of various polymers and polymer blends (56).

The filaments used for FDM are mostly prepared by the hot melt extrusion (HME) process, where the drug is incorporated into the polymer along with various excipients. This process uses a screw-based extrusion system in a barrel, which is driven by a motor and uses heat and pressure to melt the mixture, which is then left to cool down. This mixture then hardens to produce the filament which is to be used as the feed for FDM $(56,57)$. The wide use of FDM in pharmaceuticals is attributed to its cost-effectiveness, printing accuracy, guaranteed quality parameters and the incorporation of HME (58).

Direct powder 3D printing (DPP), which is a one-step FDM process without HME was researched on. Here, the powder blends after loading into a stainless steel extrusion cartridge, were heated and successfully printed to fabricate tablets with a honeycomb design (59).

\section{Pharmaceutical Applications of FDM}

There has been a plethora of research on FDM"s capabilities to develop various pharmaceutical products (Table I). Tablets of various shapes and release profiles $(60,64,66)$, bilayer tablets $(69,70)$, and tablet in device systems (77) were fabricated. Sustained release capsule shaped tablets (Caplets) of theophylline were developed (78). Development

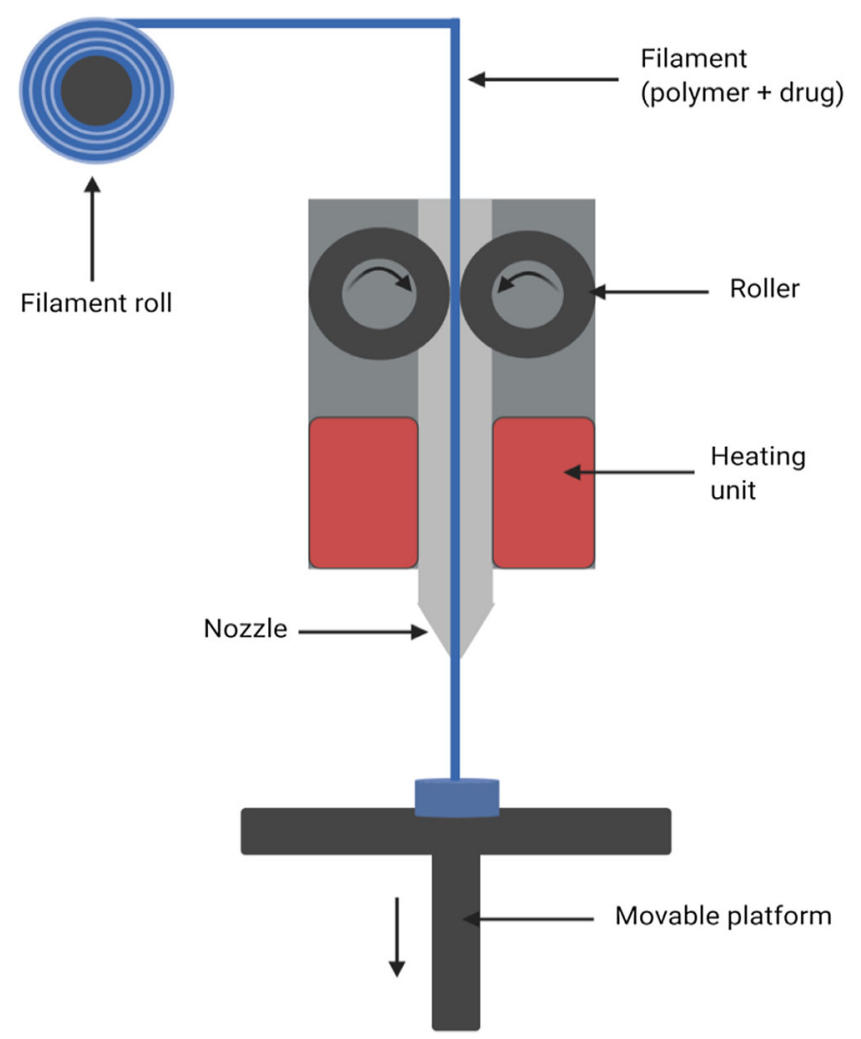

Fig. 3. Schematic of fused deposition modeling

of capsules (87) and multi-compartmental capsules (88) were also carried out.

In the last few years, there has been extensive research in the use of FDM in gastro-retentive dosage forms, from tablets $(71,72,89)$ and capsules (90) to capsular devices $(73,75,76)$ and pulsatile drug delivery systems (74). Apart from these, oral fast dissolving films (79) and mucoadhesive buccal films (80) were also fabricated. FDM was used to fabricate substrates for the deposition of drugs onto them by inkjet printing (33). Other pharmaceutical applications include microneedles (81), drug containing orthodontic retainers (84), drug containing topical masks (85), and drug-loaded vaginal rings (86). The pharmaceutical applications are summarized in Table I.

\section{Selective Laser Sintering (SLS)}

Selective laser sintering employs laser energy to heat and fuse the particles of powder, which solidify to form a $3 \mathrm{D}$ object. The main components of the selective laser sintering (SLS) system are spreading platform, powder bed, and laser system. The spreading system first spreads the powder uniformly on the platform and a roller blade is used to even the surface. The scanning pattern of the laser system, which moves in a 2-dimensional plane, is predetermined based on the properties of the finished product. The material is heated to a temperature below its melting point to cause fusion by melting using laser, and the height of the bed is altered to center laser on the freshly formed surface. The loose powder on the platform provides support during the process. Each time, the powder bed is moved down by a height of one layer and the next layer is deposited and fused. This is repeated to 
Table I. Pharmaceutical Applications of FDM

\begin{tabular}{|c|c|c|c|c|}
\hline Dosage form & $\begin{array}{l}\text { Active pharmaceutical } \\
\text { ingredient (API) }\end{array}$ & Polymers & Special characteristics & Reference \\
\hline \multirow[t]{8}{*}{ Tablets } & Tramadol & $\begin{array}{l}\text { Hydroxypropyl cellulose (HPC), } \\
\text { polyethylene oxide (PEO) }\end{array}$ & Modified release, abuse deterrent & $(60)$ \\
\hline & Bicalutamide & Kollicoat IR & Modified release & $(61)$ \\
\hline & Dronedarone $\mathrm{HCl}$ & $\begin{array}{l}\text { Polyethylene glycol (PEG), polyvinyl } \\
\text { alcohol (PVA) }\end{array}$ & - & $(62)$ \\
\hline & Metformin $\mathrm{HCl}$ & PVA & $\begin{array}{l}\text { Egg-shaped tablet-Egglet, abuse } \\
\text { deterrent }\end{array}$ & $(63)$ \\
\hline & Isoniazid & $\begin{array}{l}\text { HPC, Hydroxy propyl methyl } \\
\text { cellulose, PEO, Eudragit, Kolliphor }\end{array}$ & Modified release & (64) \\
\hline & Rebamipide & Hypermellose phthalate & Controlled drug release & $(65)$ \\
\hline & Metformin $\mathrm{HCl}$ & PVA & Ethanol-water (9:1) increased drug loading & $(66)$ \\
\hline & Carvedilol, haloperidol & PVA & Rapid drug release & $(67)$ \\
\hline Osmotic tablets & Diltiazem & $\begin{array}{l}\text { Core-PVA } \\
\text { Shell-cellulose acetate }\end{array}$ & Shape of CA varied which modified release & $(68)$ \\
\hline \multirow[t]{2}{*}{ Bilayer tablets } & $\begin{array}{l}\text { Enalapril maleate, } \\
\text { Hydrochlorothiazide }\end{array}$ & Eudragit & Dynamic dose dispensing & $(69)$ \\
\hline & $\begin{array}{l}\text { M e t f o r m i n } \\
\text { Glimepiride }\end{array}$ & Eudragit, PVA & Combination of two release profiles & $(70)$ \\
\hline \multirow[t]{2}{*}{$\begin{array}{l}\text { Gastro-retentive } \\
\text { tablets }\end{array}$} & Cinnarizine & $\begin{array}{l}\text { HPC, vinyl pyrrolidone-vinyl acetate } \\
\text { copolymer (Kollidon) }\end{array}$ & Controlled release & $(71)$ \\
\hline & Theophylline & $\mathrm{HPC}$ & Controlled release & $(72)$ \\
\hline \multirow{5}{*}{$\begin{array}{l}\text { Gastro-retentive } \\
\text { floating devices }\end{array}$} & Acyclovir & Polylactic acid (PLA) & Tablet in device, controlled release & (73) \\
\hline & Theophylline & HPC, ethyl cellulose & Tablet in device, pulsatile drug release & (74) \\
\hline & Baclofen & PLA & Tablet in device, sustained release & $(75)$ \\
\hline & Amoxicillin & PVA & Capsule in device, prolonged drug release & (76) \\
\hline & Riboflavin & PLA, poly caprolactone (PCL) & Tablet in device, controlled release & (77) \\
\hline Caplets & Theophylline & HPC, Eudragit, PEG & Sustained release & $(78)$ \\
\hline $\begin{array}{l}\text { Fast dissolving oral } \\
\text { films }\end{array}$ & $\begin{array}{l}\mathrm{P} \text { a } \mathrm{r} \text { a c e } \mathrm{t} \text { a } \mathrm{m} \mathrm{o} 1 \\
\text { Ibuprofen }\end{array}$ & PEO, PVA & $\begin{array}{l}\text { Single-layered or multilayered films with } \\
\text { circular, square, and mesh shape }\end{array}$ & $(79)$ \\
\hline Mucoadhesive & Diclofenac sodium & PVA & - & $(80)$ \\
\hline buccal films & Ibuprofen & HPMC & Drug loading was done by inkjet printing & (33) \\
\hline Microneedles & Fluorescein & PLA & - & $(81)$ \\
\hline Suppository shell & Progesterone & PVA & Holes were made in the shell & $(82)$ \\
\hline Meshes & Ciprofloxacin & Polypropylene, PVA & - & (83) \\
\hline $\begin{array}{l}\text { Orthodontic } \\
\text { retainers }\end{array}$ & Clonidine $\mathrm{HCl}$ & PLA, PCL & Local sustained release of drug & (84) \\
\hline Anti acne mask & Salicylic acid & Flex Eco PLA and PCL & Nose-shaped masks & $(85)$ \\
\hline Vaginal rings & Progesterone & PLA, PCL & Controlled release & (86) \\
\hline
\end{tabular}

construct the final 3D printed object, which after cooling inside the printer, is gathered from the loose powder manually or by using a sieve (91) (Fig. 4). This method is advantageous as it is a one-step fast production process and does not use any solvent. It also produces objects with high resolution due to the laser precision (92).

\section{Pharmaceutical Applications of SLS}

SLS is not so widely used in the production of drugloaded formulations due to the high energy laser, which might degrade the drugs (92). Various delivery devices for drug loading using SLS have been explored $(93,94)$.

Recently, development of oral drug-loaded formulations using SLS has been researched. 3D printed tablets (printlets) of paracetamol were developed using two polymers, namely Kollicoat and Eudragit, which showed no evidence of drug degradation (92). Orally disintegrating printlets of paracetamol using polymers HPMC and kollidon were fabricated (95). Printlets of ondansetron were used for the complexation after incorporation into cyclodextrin with mannitol and kollidon (96). Various mini-printlets combining paracetamol and ibuprofen with customized drug release patterns were also investigated (97). Paracetamol-loaded gyroid structures were also developed using polymers polyethylene oxide, Eudragit and ethyl cellulose (98).

\section{Stereolithography (SLA)}

Stereolithography is based on the hardening of liquid resin by photo-polymerization using ultraviolet light. The setup of the printer can either be bottom-up, where the UV source is located below the printer and the moving platform above, or top-down, where the UV source is above and the platform is below. The first layer, after being traced by the laser in the $\mathrm{x}$ and $y$-axis directed by scanning mirrors, gets 


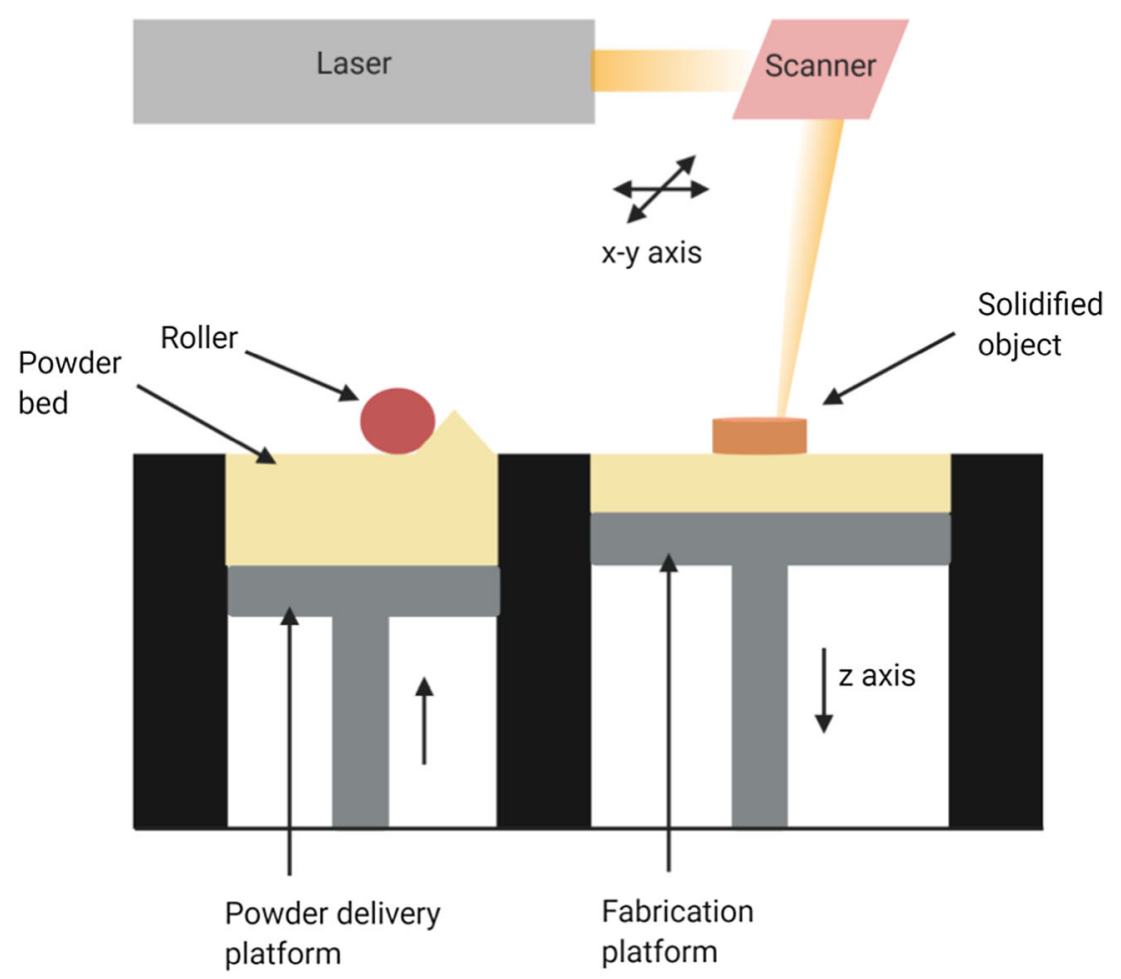

Fig. 4. Schematic of selective laser sintering

photo-cured and attaches to the building platform. The platform then moves across the $z$-axis to an extent which depends on the width of each layer (moved down in case of bottom-up approach and elevated in case of top-down approach). Following this, the liquid resin is redistributed above the previously hardened layer for its hardening and the process is continued to build the 3D object (Fig. 5). The object is then cleansed with alcohol to get rid of the excess resin. Post-curing can be employed using a UV oven to strengthen the object $(22,99)$.

The materials used for SLA must have photo-curable characteristics in order to undergo photo-cross-linking. The advantages of this printing process include high resolution and low thermal stress involved.

\section{Pharmaceutical Applications of Stereolithography}

Despite its advantages, this printing process has a limited application in the pharmaceutical sector. One reason being the smaller number of adequate polymers for pharmaceutical use, none of which have been listed as generally recognized as safe (GRAS) substances. Hence, they are not suitable for human use and also have stability issues due to their photosensitivity. Another limitation is that the photoinitiator fragments might get trapped in the photopolymerized structures, which upon leaching out of the structure can prove to be cytotoxic (99). Also, one of the studies found an unexpected chemical reaction, i.e., a Michael addition reaction between the photo-polymer and drug (100).

Wang and team successfully employed SLA printing to construct paracetamol tablets with modified release profiles using polyethylene glycol di-acrylate as the monomer and diphenyl (2,4,6-trimethylbenzoyl) phosphine oxide as the photo-initiator (101). It was also used to develop paracetamol tablets of various shapes to obtain different release profiles (102).

Hydrogels have also been developed using this technology. Martinez and team prepared hydrogels loaded with ibuprofen consisting of cross-linked polyethylene glycol diacrylate. It was shown that hydrogels that contained and retained water could be printed by the addition of water to the resin formulation and this is because water can be trapped in the matrices (103). Ascorbic acid-loaded solid dosage hydrogels were also fabricated using the polymer poly(ethylene glycol) di-methacrylate and riboflavin as the photoinitiating substance (104).

Various microneedles for transdermal delivery were also fabricated, which were then coated by the drug using inkjet printing (39,105). A novel, hybrid manufacturing process was developed for drug delivery systems incorporated with drug depots, where the matrix of the DDS was generated by SLA and loading of drug depots was done using inkjet printing (106). Microreservoirs for implantable and transdermal delivery were developed (107). Goyanes and associates developed salicylic acid-based anti-acne masks using FDM and SLA. In the SLA prepared masks, mixtures of PEGDA and PEG were used. SLA was concluded as the superior method due to higher resolution, higher loading of drug and the absence of drug degradation (85).

\section{Pressure assisted microsyringe (PAM)}

Pressure-assisted microsyringe involves a syringe-based head fed with semi-solid material from which the material is extruded continuously, in a layer upon layer fashion, to construct a 3D printed object (Fig. 6). The extrusion can be based on a mechanical, pneumatic or solenoid piston. The semi-solid mixture consists of a suitable mixture of polymer, 

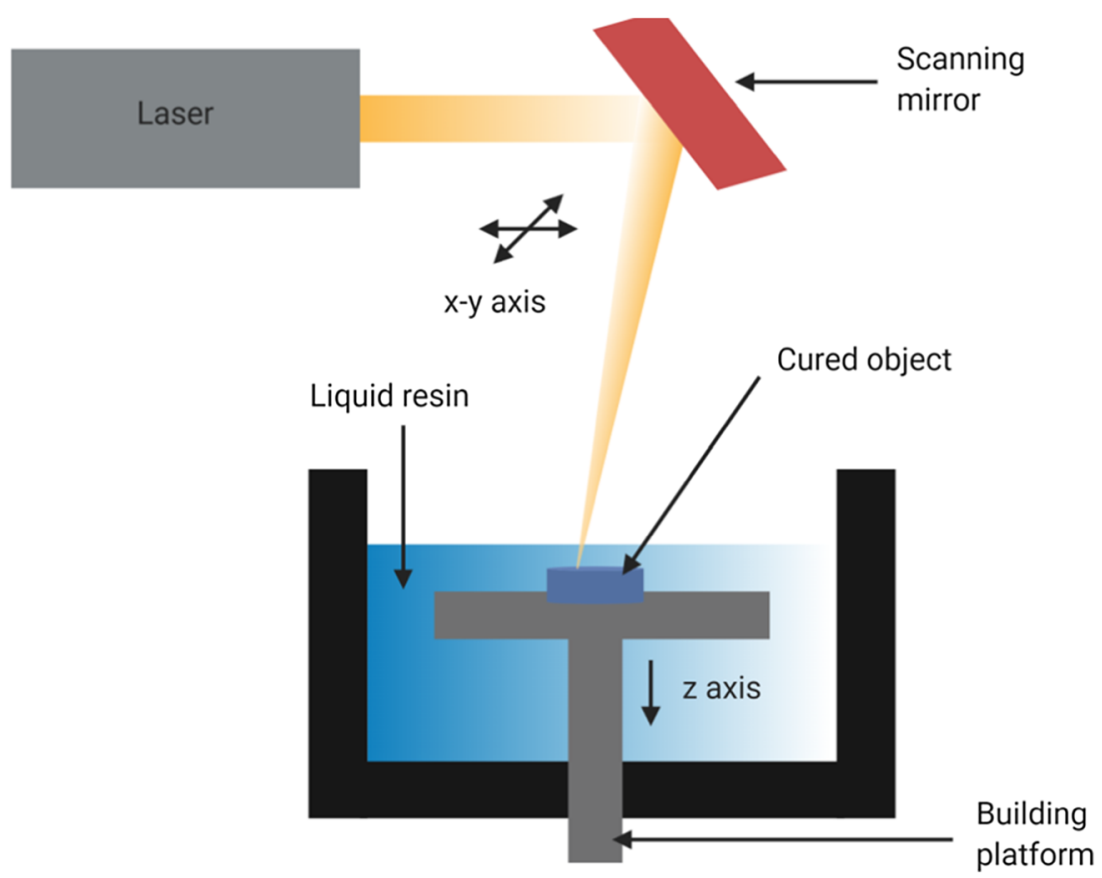

Fig. 5. Schematic of stereolithography

solvent, and additional necessary excipients that have properties suitable for printing. Drying after the printing process becomes crucial because of the use of solvents, which might in turn lead to shrinking or deformation of the final product. Also, if the deposited layer does not strengthen enough to overcome the weight of the succeeding layers, the printed object might collapse. The main advantage of this process is the absence of high temperatures (108).

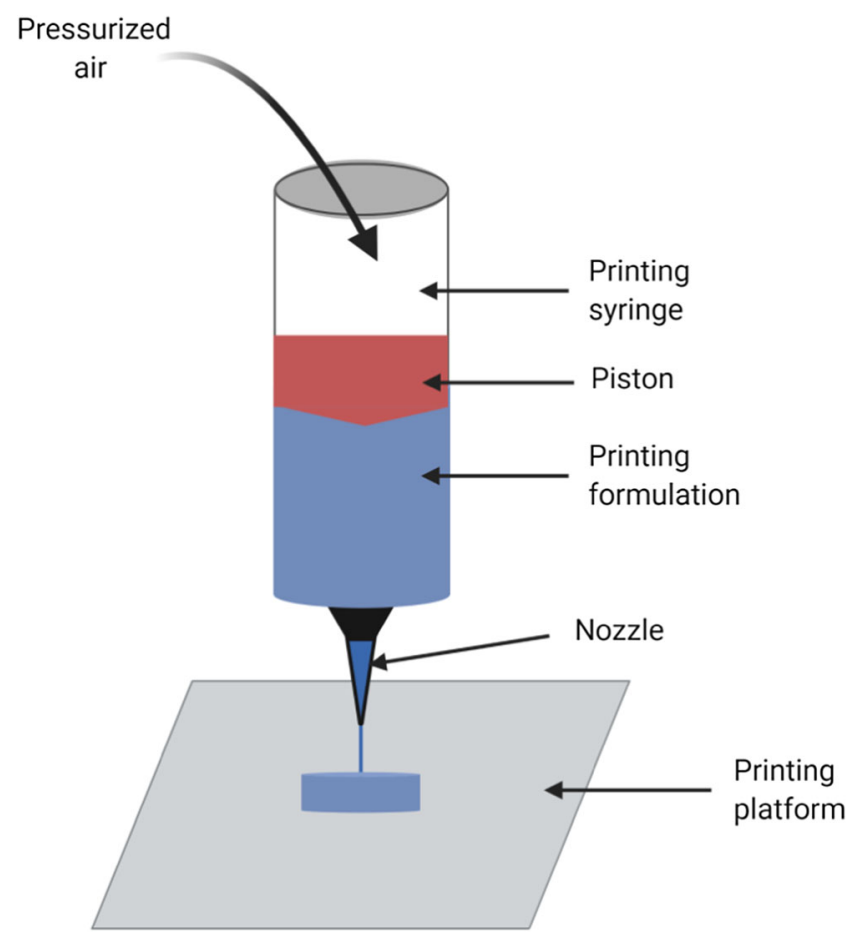

Fig. 6. Schematic of pressure-assisted microsyringe

\section{Pharmaceutical Applications of Pressure-Assisted Microsyringe}

Aita et al. used pressure-assisted microsyringe (PAM) to develop immediate release tablets of levetiracetam which were free of organic solvents. Polyvinyl alcohol-polyethylene glycol graft co-polymer was employed as the matrix, and the effect of another polymer, polyvinyl pyrrolidone-vinyl acetate co-polymer on the tablets was determined. The tablets with additional PVP-PVAc showed increase in dissolution and disintegration time (109). The same team then developed tablets using polyvinyl acetate/polyvinyl pyrrolidone copolymer, HPMC and highly dispersed silicon dioxide where the dissolution profiles could be altered by modifying the amount of HPMC (110).

HPMC-based gastro-retentive tablets of ginkgolide were prepared using PAM. Lactose and microcrystalline cellulose were used to form a homogenous paste, to increase the formability (111). Mucoadhesive oral films of HPMC loaded with catechin were prepared using hydrogel-based printer inks (112).

Table II shows a brief comparison of the various 3D printing technologies, along with their advantages and disadvantages. Table III summarizes some studies under each technology from the literature.

\section{POTENTIAL OF 3D PRINTING IN PERSONALIZED MEDICINE}

One of the major potentials of $3 \mathrm{D}$ printing in the pharmaceutical sector is its ability to tailor the dosage forms to individuals. This can be done by fabricating adequate dosage forms, adjusting the doses, combining them or by varying the release profiles of the dosage forms according to the need of patients. 
Table II. Comparison of Various 3D Printing Technologies

\begin{tabular}{|c|c|c|c|}
\hline Method & Material & Advantages & Disadvantages \\
\hline Inkjet & $\begin{array}{l}\text { Ink-drug solution } \\
\text { Substrate-polymer- } \\
\text { based films }\end{array}$ & $\begin{array}{l}\text { - Continuous inkjet-prevents clogging of nozzle } \\
\text { - Drop-on-demand inkjet-high precision, low } \\
\text { cost and minimizes wastage of material }\end{array}$ & $\begin{array}{l}\text { - Continuous inkjet-wastage of material, } \\
\text { low resolution, and expensive } \\
\text { - TIJ_might degrade heat sensitive ma- } \\
\text { terials }\end{array}$ \\
\hline Binder jet & Binder fluid, powder bed & $\begin{array}{l}\text { - Can be performed at room temperature } \\
\text { - Use of a wide range of starting material } \\
\text { - Fast disintegrating dosage forms can be } \\
\text { produced }\end{array}$ & $\begin{array}{l}\text { - Post-fabrication drying becomes neces- } \\
\text { sary } \\
\text { - Use of organic solvents } \\
\text { - Wastage of powder material } \\
\text { - Produces fragile dosage forms }\end{array}$ \\
\hline $\begin{array}{l}\text { Fused deposition } \\
\text { modelling }\end{array}$ & $\begin{array}{l}\text { Thermoplastic polymeric } \\
\text { filaments }\end{array}$ & $\begin{array}{l}\text { - Comparatively low-cost process } \\
\text { - Solvent-free process } \\
\text { - No post-fabrication steps } \\
\text { - Produces mechanically strong dosage forms }\end{array}$ & $\begin{array}{l}\text { - Heat involved might degrade certain } \\
\text { material } \\
\text { - Polymers used must be thermoplastic } \\
\text { - Prior preparation of filaments necessary }\end{array}$ \\
\hline $\begin{array}{l}\text { Selective laser } \\
\text { sintering }\end{array}$ & $\begin{array}{l}\text { Laser energy absorbing } \\
\text { powder }\end{array}$ & $\begin{array}{l}\text { - One step fast production process } \\
\text { - Solvent-free process } \\
\text { - Produces objects with high resolution }\end{array}$ & $\begin{array}{l}\text { - Only laser energy absorbing components } \\
\text { can be used } \\
\text { - High energy laser might degrade drugs }\end{array}$ \\
\hline Stereolithography & Photo-curable liquid resin & $\begin{array}{l}\text { - High-resolution process } \\
\text { - Low thermal stress involved }\end{array}$ & $\begin{array}{l}\text { - Starting materials must have photo- } \\
\text { curable characteristics } \\
\text { - Post-curing steps necessary } \\
\text { - Less number of polymers approved for } \\
\text { pharmaceutical use } \\
\text { - Stability issues while storing photo- } \\
\text { sensitive resins } \\
\text { - Products can be cytotoxic }\end{array}$ \\
\hline $\begin{array}{l}\text { Pressure-assisted } \\
\text { microsyringe }\end{array}$ & $\begin{array}{l}\text { Semi-solid mixture of } \\
\text { polymers and solvents }\end{array}$ & $\begin{array}{l}\text { - Room temperature process } \\
\text { - Wide range of starting material can be used }\end{array}$ & $\begin{array}{l}\text { - Use of organic solvents } \\
\text { - Post-fabrication drying necessary }\end{array}$ \\
\hline
\end{tabular}

\section{Dose Personalization}

3D printing can offer potential in achieving flexibility of doses according to the patient needs. One major population group that calls for dose flexibility is the pediatric group in which the therapeutic dose varies according to the age and body weight of children. Various dosage forms mentioned above can be adequately modified using $3 \mathrm{D}$ printers to dispense the best dose for patients. In ODF formulations, this can be easily done by modulating the amount of liquid API dispensed on the film. ODFs can also be subjected to changes in shape and dimension to individualize treatments (29). Likewise, dose strength can be modified in other dosage forms like tablets or patches to tailor them for patient needs. For example, Pietrzak et al. used FDM and HME to print theophylline tablets of doses varying from 60 to $300 \mathrm{mg}$ by manipulating the printing scale (122).

In the past years, tablet splitting by hand or by using a splitter, has been undertaken to achieve dose flexibility. This has been proven to be ineffective as the various characterization parameters of the subdivided tablets do not always comply with the Pharmacopoeial standards. Zheng et al. carried out the research where split tablets were compared with $3 \mathrm{D}$ printed subdivided tablets. The $3 \mathrm{D}$ printed subdivided tablets were concluded to be more accurate, safe, and had the potential for customization (122). 3D printed pellets or mini-printlets, which are mini-tablets, have been developed, and these can be personalized. They can also be used to combine two different drugs (97). Mini-printlets can also be combined and encapsulated according to the dose necessary to achieve personalization (123).

\section{Modifying Release Profiles}

$3 \mathrm{D}$ printing can be employed to obtain dosage forms of various release profiles which can be tailored to individual requirements. One of the techniques to attain this is by altering tablet shapes and geometries. Immediate release tablets of a low dose drugs were fabricated, where it was concluded that by decreasing the tablet thickness or by generating spaces in them, the drug release rates increased and complete release was achieved at times as low as $5 \mathrm{~min}$ (124). Khaled et al. developed paracetamol tablets of various geometries, namely ring and mesh, and compared them with each other and solid tablets. Immediate release was achieved with the mesh tablets, whereas ring and solid tablets demonstrated sustained release (125).

In another study, paracetamol tablets of the shapes cube, disc, sphere, pyramid, and torus were fabricated. The study concluded that the drug release form the printlets can be modified by altering the surface area/volume ratio (102). Tablets of complex geometries like that of a honeycomb structure were fabricated using $3 \mathrm{D}$ printing. The honeycomb cell sizes were varied from 0.20 to $1.83 \mathrm{~mm}$ to obtain various release profiles. It was concluded that dosage form geometries could be manipulated to achieve different release profiles (126).

Tablets of complex release profiles which combined two different release mechanisms were also fabricated. This included immediate-extended release tablets with two sections of varying $\mathrm{pH}$-based release mechanisms. Breakaway tablets comprising of three sections, i.e., two drugs containing subsections which eroded within $45 \mathrm{~min}$ in an environment 
Table III. Some 3D Printing Studies from the Literature

\begin{tabular}{|c|c|c|c|c|c|c|}
\hline Method & Year & Dosage form & Drug/biologic & Objective & Outcome & References \\
\hline \multirow[t]{5}{*}{ Inkjet } & 2017 & Scaffold & $\begin{array}{l}\text { Lid o c a in e } \\
\text { hydrochloride, } \\
\text { piroxicam }\end{array}$ & $\begin{array}{l}\text { To study the use of electrospun } \\
\text { fibrous substrates for the fabrication } \\
\text { of inkjet-printed dosage forms }\end{array}$ & $\begin{array}{l}\text { - Good entrapment and solidification } \\
\text { of the drug in the matrix } \\
\text { - Printed drug amount in good } \\
\text { correlation with theoretical dose }\end{array}$ & (34) \\
\hline & 2018 & Buccal film & Lysozyme & $\begin{array}{l}\text { To study the effects of printing } \\
\text { biologics on films in terms of their } \\
\text { physical and mucoadhesive properties }\end{array}$ & $\begin{array}{l}\text { - Printing successful without affecting } \\
\text { mechanical or mucoadhesive } \\
\text { properties }\end{array}$ & (36) \\
\hline & 2019 & $\begin{array}{l}\text { Transdermal } \\
\text { patch }\end{array}$ & Indomethacin & $\begin{array}{l}\text { To study the application of PIJ in the } \\
\text { development of indomethacin films }\end{array}$ & $\begin{array}{l}\text { - Patches loaded with indomethacin } \\
\text { alcoholic solution showed crystalline } \\
\text { structure, whereas the addition of } \\
\text { PVP showed amorphous form } \\
\text { - Patches showed good drug release } \\
\text { and permeation }\end{array}$ & $(38)$ \\
\hline & 2020 & Buccal film & $\begin{array}{l}\text { Ketoprofen, } \\
\text { li d o c a i n e } \\
\text { hydrochloride }\end{array}$ & $\begin{array}{l}\text { To fabricate and evaluate buccal films } \\
\text { by combining FDM and inkjet } \\
\text { printing }\end{array}$ & $\begin{array}{l}\text { - Alterations in the characteristics of } \\
\text { films observed } \\
\text { - Mucoadhesive and mechanical } \\
\text { properties effectively modified } \\
\text { - Films showed good release and lack } \\
\text { of any toxicity }\end{array}$ & (113) \\
\hline & 2020 & Buccal film & $\begin{array}{l}\mathrm{T} \text { h i a } \mathrm{m} \text { i n e } \\
\text { hydrochloride, } \\
\text { nicotinic acid }\end{array}$ & $\begin{array}{l}\text { To fabricate and evaluate buccal films } \\
\text { comprising of B-complex vitamins }\end{array}$ & $\begin{array}{l}\text { - Inkjet printing did not affect the solid } \\
\text { state of the matrix } \\
\text { - Burst release of both vitamins within } \\
10 \text { min } \\
\text { - Higher concentrations of vitamins } \\
\text { onto the substrate improved in vitro } \\
\text { permeation }\end{array}$ & (114) \\
\hline \multirow[t]{3}{*}{$\begin{array}{l}\text { Binder } \\
\text { jet }\end{array}$} & 2018 & Tablet & Caffeine & $\begin{array}{l}\text { To evaluate various HPC grades as } \\
\text { solid binders in the powder } \\
\text { formulation to print tablets }\end{array}$ & $\begin{array}{l}\text { - HPC was a suitable binder for binder } \\
\text { jetting } \\
\text { - Tablet friability depended on the } \\
\text { particle size of the binder } \\
\text { - Disintegration and dissolution time } \\
\text { depended on the viscosity of the } \\
\text { binder }\end{array}$ & $(49)$ \\
\hline & 2020 & Tablet & $\begin{array}{l}\text { Amitriptyline } \\
\text { hydrochloride }\end{array}$ & $\begin{array}{l}\text { To fabricate tablets using binder jet } \\
\text { printing and evaluate the drug loading } \\
\text { efficiency of the printing process }\end{array}$ & $\begin{array}{l}\text { - The minimum drug loading was } \\
30 \mu \mathrm{g} \\
\text { - Tablets had a porous surface } \\
\text { - They showed immediate release }\end{array}$ & $(55)$ \\
\hline & 2020 & Tablet & Indomethacin & $\begin{array}{l}\text { To study various powders and liquid } \\
\text { binders as possible materials for } \\
\text { binder jet printing }\end{array}$ & $\begin{array}{l}\text { - A moulding method was developed } \\
\text { to select appropriate powder and } \\
\text { binder materials } \\
\text { - The polymer Kollidon produced } \\
\text { tablets with a higher breaking force } \\
\text { - Disintegration time of the printed } \\
\text { tablets were shorter than their } \\
\text { moulded counterparts } \\
\text { - Breaking force of the printed tablets } \\
\text { limited by the amount of binder jetted } \\
\text { - Spraying water onto the tablets after } \\
\text { printing increased the breaking force }\end{array}$ & (115) \\
\hline \multirow[t]{2}{*}{ FDM } & 2017 & $\begin{array}{l}\text { Orodispersible } \\
\text { film }\end{array}$ & Aripiprazole & $\begin{array}{l}\text { To fabricate and evaluate } \\
\text { orodispersible films of aripiprazole }\end{array}$ & $\begin{array}{l}\text { - PVA was concluded to be a suitable } \\
\text { polymer for orodispersible film } \\
\text { fabrication } \\
\text { - Amorphization of aripiprazole was } \\
\text { achieved which led to increase in } \\
\text { dissolution rate } \\
\text { - Mechanical properties of the printed } \\
\text { films were comparable with the casted } \\
\text { films }\end{array}$ & (116) \\
\hline & 2018 & $\begin{array}{l}\text { Table t in } \\
\text { device }\end{array}$ & Riboflavin & $\begin{array}{l}\text { To design and evaluate a gastric } \\
\text { floating system where a tablet is } \\
\text { accommodated into a device }\end{array}$ & $\begin{array}{l}\text { - Device showed good floating ability } \\
\text { and optimal drug release } \\
\text { - Floating time reached more than } \\
3 \text { days }\end{array}$ & (77) \\
\hline
\end{tabular}


Table III. (continued)

\begin{tabular}{llll}
\hline Method & Year & Dosage form & Drug/biologic \\
2019 & Tablet & Pregabalin
\end{tabular}

Objective

To fabricate a floating sustained release system
Outcome

- Processing conditions did no

significantly affect the drug stability

- Crystallinity of the drug retained even after printing

- Drug release was quicker from an open system with low infill percentage compared with closed systems with high infill percentage

- Tablet with partially opened top layer exhibited zero-order drug release
2020 Tablet

2020 Tablet

2020 Tablet

SLS 2017 Tablet

2018 Tablet

2020 Tablet

2020 Tablet
Paracetamol

Rufinamide

Cinnarizine

Paracetamol

Paracetamol

Ondansetron

To fabricate and evaluate orodispersible printlets of ondansetron

Clindamycin To fabricate and evaluate clindamycin $\mathrm{P}$ a $1 \mathrm{mit}$ a t e printlets by SLS hydrochloride

To investigate the feasibility of SLS to fabricate orally disintegrating tablets with accelerated release fabrication of tablets using polymers, Kollicoat and Eudragit

rufinamide through solid dispersions using $3 \mathrm{D}$ printing retentive dosage form of cinnarizine (mini-printlets) with modified release using SLS
- Tablets showed zero order release profiles for 16-48 h

- Dose contained in the tablet could be infinitely adjusted for personalized medicine

- A mixture of HPMC, Kollidon, Soluplus, Triacetin and gelucire were the suitable excipients to improve the dissolution floating force was constant up to $12 \mathrm{~h}$

- Drug release followed zero order kinetics and was controlled from $6 \mathrm{~h}$ to $\geq 12 \mathrm{~h}$

- Printing parameters and design had a good correlation with tablet performance

- Printed tablets were robust

- No evidence of drug degradation observed

- Kollicoat formulations showed $\mathrm{pH}$ independent release which depended on drug content

- Eudragit formulations showed $\mathrm{pH}$ dependent release, independent of drug loading

- Modifying the laser scanning speed of the SLS printer affected the release characteristics and accelerated release tablets were obtained

- Tablets of 1 and $2 \mathrm{~mm}$ diameter were

fabricated

- Ethyl cellulose-based printlets exhibited prolonged drug release

- Dual printlets with customised release patterns were obtained by varying the polymer

- Tablets fabricated disintegrated at $15 \mathrm{~s}$ and $>90 \%$ drug released within $5 \mathrm{~min}$ microcrystalline cellulose and lactose monohydrate affected tablet properties

- Decrease in crystallinity of lactose monohydrate observed in printlets

SLA 2017 Hydrogel Ibuprofen

To fabricate and evaluate ibuprofen-

loaded hydrogels of cross-linked poly- water were prepared ethylene glycol diacrylate

- Hydrogels with higher water content released the drug faster

2018 Microneedles Insulin

To fabricate and evaluate polymeric microneedle patches for transdermal delivery of insulin
The tablets floated instantly, and the

Laser scanning speed, amount of

References

Pyramid and cone shaped were coated using inkjet printing 
Table III. (continued)

\begin{tabular}{|c|c|c|c|c|c|c|}
\hline \multirow[t]{4}{*}{ Method } & Year & Dosage form & Drug/biologic & Objective & $\begin{array}{l}\text { Outcome } \\
\text { - Insulin integrity and stability was } \\
\text { preserved } \\
\text { - Insulin was released within } 30 \text { min } \\
\text { irrespective of microneedle design }\end{array}$ & References \\
\hline & 2019 & Microneedles & Cisplatin & $\begin{array}{l}\text { To fabricate and evaluate polymeric } \\
\text { microneedle arrays for the delivery of } \\
\text { cisplatin }\end{array}$ & $\begin{array}{l}\text { - Excellent piercing ability observed } \\
\text { with } 80 \% \text { penetration } \\
\text { - Good release rates and anti-cancer } \\
\text { activity observed }\end{array}$ & (105) \\
\hline & 2019 & Tablet & $\begin{array}{l}\text { Paracetamol, } \\
\text { Aspirin }\end{array}$ & $\begin{array}{l}\text { To fabricate and evaluate tablets of } \\
\text { two drug concentrations }(2.5 \% \text { and } \\
5 \%) \text { using SLA }\end{array}$ & $\begin{array}{l}\text { - } 28 \text { dosage forms were successfully } \\
\text { fabricated in one print process } \\
\text { - Sustained release over } 24 \text { h observed } \\
\text { - Statistically significant differences } \\
\text { were observed from target range, } \\
\text { indicating scope for process } \\
\text { improvement }\end{array}$ & $(121)$ \\
\hline & 2020 & Hydrogel & Ascorbic acid & $\begin{array}{l}\text { To employ SLA to create custom } \\
\text { hydrogel tablet geometries using a } \\
\text { water soluble and novel resin }\end{array}$ & $\begin{array}{l}\text { Poly (e thyle n e glycol) } \\
\text { dimethacrylate-based polymer net- } \\
\text { work was employed to create various } \\
\text { geometries } \\
\text { - Honeycomb and coaxial annulus } \\
\text { tablet gels showed highest release }\end{array}$ & (104) \\
\hline \multirow[t]{3}{*}{ PAM } & 2018 & Tablet & Levetiracetam & $\begin{array}{l}\text { To fabricate and evaluate tablets using } \\
\text { polyvinyl alcohol-polyethylene glycol } \\
\text { (PVA-PEG) copolymer and checking } \\
\text { the effects of another polymer polyvi- } \\
\text { nyl pyrrolidone-vinyl acetate (PVP- } \\
\text { PVAc) copolymer on the properties } \\
\text { of the tablet }\end{array}$ & $\begin{array}{l}\text { - Tablets with PVA-PEG showed im- } \\
\text { mediate release within } 10 \text { min } \\
\text { - Addition of PVP-PVAc showed } \\
\text { slight delay } \\
\text { - Tablets with PVA-PEG disintegrated } \\
\text { faster than PVP-PVAc }\end{array}$ & (109) \\
\hline & 2018 & Tablet & Ginkgolide & $\begin{array}{l}\text { To develop and evaluate a gastro- } \\
\text { retentive, controlled release } \\
\text { formulation }\end{array}$ & $\begin{array}{l}\text { - Tablets had good mechanical } \\
\text { properties } \\
\text { - Effect of various printing parameters } \\
\text { on the tablet was studies }\end{array}$ & (111) \\
\hline & 2020 & Tablet & Levetiracetam & $\begin{array}{l}\text { To develop formulations for PAM } \\
\text { which are free of organic solvents } \\
\text { and have a good long-term stability }\end{array}$ & $\begin{array}{l}\text { - Drug release could be modified by } \\
\text { varying the amount of HPMC and by } \\
\text { changing the infill design } \\
\text { - Tablets had a high structural } \\
\text { integrity, uniform content and mass }\end{array}$ & (110) \\
\hline
\end{tabular}

mimicking the GIT, separated by an interior fast eroding section, were fabricated. Enteric dual pulsatory tablets were also constructed, which showed two pulses of release at 1 and 8 h. Also, dual pulsatory tablets were developed with two sections of opposing $\mathrm{pH}$-based solubility in which one section eroded in the acid dissolution stage within $30 \mathrm{~min}$ and the second one began eroding $5 \mathrm{~h}$ later at the higher $\mathrm{pH}$ stage (51).

Apart from solid tablets, shape was also varied for 3D designed patches. Three shapes of fish gelatin-based polymer hydrogel patches, i.e., cylinder, torus and gridlines, were developed which showed variable drug release (127). Also, optimized capsular devices were fabricated, which were used to control drug release from an immediate release tablet inside them, while being suspended in the gastric fluid (75).

Gioumouxouzis et al. fabricated osmotic 3D printed dosage forms where the release was altered by altering the shape of the cellulose acetate shell enclosing the osmotic core (68). Another study concluded that in coated tablets, the area of tablet coated, number of coats, and coated sides of the tablets were the parameters which controlled release profile of drugs (128).
Apart from variations in the structure and coating, the excipients used can also moderate drug release by $3 \mathrm{D}$ printing. Wang et al. used SLA to fabricate tablets of 4aminosalicylic acid and paracetamol. They concluded that the drug release depends on the percentage of cross-linkable polymers. Higher ratios of poly(ethylene glycol) diacrylate in the tablets decreased the rate of dissolution whereas higher concentration of PEG 300 enhanced the release (101). Tagami et al. developed tablets of naftopidil using a semisolid extrusion type 3D printer where hydrogel was used as the printer ink. It was found that increasing the quantity of HPMC in the formulation retarded drug release (129).

\section{Combination Tablets-Polypills}

One of the significant applications of 3D printing in personalized medicine is a concept of "polypill". A polypill composes of a combination of many drugs in a single tablet which can be tailored for an individual undergoing polypharmacy. Also, the drug release can be tailored as per individual needs. This concept can widely benefit the geriatric populations, where it can improve patient compliance and 
medication adherence as it reduces the number of pills consumed in a day. Khaled et al. successfully fabricated 3D printed polypills with three drugs which could be a possible medication for diabetics with hypertension. These pills compose of an osmotic compartment of captopril and sustained release compartments of nifedipine and glipizide (130). The same team also devised a polypill with five compartments which represented a cardiovascular treatment regimen. The tablet composed of aspirin and hydrochlorothiazide in two immediate release compartments and pravastatin, atenolol, and ramipril in three sustained release chambers (131).

Another team developed PVA-based polypills comprising of four drugs-lisinopril, amlodipine, rosuvastatin, and indapamide-which were explored for multilayer and unimatrix structures. The unimatrix tablets resulted in slower drug release than individual tablets. In the multilayered polypills, the drug release was influenced by its location in the multilayer (132). Martinez et al. fabricated multilayered polypills comprising of 6 drugs-paracetamol, prednisolone, aspirin, chloramphenicol, naproxen, and caffeine with different geometries, i.e., cylindrical and ring-shaped, using SLA $3 \mathrm{D}$ printer. Here, the printer was modified such that the printer could be stopped, resin tray removed, and replaced with different resin solutions (133).

The 3D printing technology was then taken further to develop polypill capsules with varying release profiles for multiple drugs. This was achieved by combining FDM with hot-filling syringes. Two capsule skeletons were designed which had four separate compartments-one with a concentrical configuration with two outer compartments for early release and two inner compartments for retarded release, other with a parallel configuration where nondissolving capsule shells with free pass corridors and dissolution rate limiting pores were used to achieve early and retarded release. The capsule shell composed of polyvinyl alcohol and polylactic acid. Customized release profiles were obtained through the alteration of shell thickness in the concentric configuration or size of rate limiting orifices in the parallel configuration (134).

\section{D Printing Tending to All Population}

\section{Tending to Pediatrics}

Children seem to be the most difficult of the population to satisfy because of their individual preferences when it comes to the dosage form, taste, shape or smell. Oral delivery might seem to be the most convenient, but might become rather complex when it comes to children. A child may simply reject a dosage form or another because of minor attributes such as preferences in the shape, color or taste. This is where $3 \mathrm{D}$ printing can come in and tend to their individual choices (135). A major concern in treating children is the administration of adequate doses according to the body weight, which can be solved using 3D printing, like mentioned above.

Swallowing being a concern in smaller children, ODF formulations, fast disintegrating tablets and mini-pills fabricated by $3 \mathrm{D}$ printing seem to be suitable for administration. A study highlighting the dosage form preferences in children concluded that children preferred mini-tablets of $4 \mathrm{~mm}$ diameter over other formulations (136). Another study concluded that, in pediatrics, ODF formulations are more suitable than oral powders in unit dose sachets (137).

Medication adherence and compliance in children can be increased by giving them dosage forms in a flavor and color of their choice. Goyanes et al. conducted a study where they used $3 \mathrm{D}$ printing to fabricate chewable tablets of isoleucine for the treatment of maple syrup urine disease (MSUD). Apart from printing the tablets in different doses as per the requirements, they successfully printed tablets in various flavors (lemon, coconut, banana, raspberry, etc.) and colors (yellow, black, light green, orange, etc.) which were well accepted by pediatric patients according to their preferences (138). Another study successfully fabricated children-friendly chewable chocolate-based dosage forms in various shapes (139).

\section{Tending to Geriatrics}

In most of the geriatric population, swallowing tablets becomes a major challenge which can influence medication adherence as swallowing difficulties increase with advancing age (140). This can be resolved by using fast disintegration tablets and oro-dispersible film formulations which can be fabricated by $3 \mathrm{D}$ printing as mentioned above.

The older population suffers from multiple ailments and requires multiple drugs and prolonged medication which brings in the issues of polypharmacy (140). Polypharmacy can be resolved by the means of poly-pills fabricated according to the patient's need by 3D printing. Some of them also suffer from cognitive impairment (dementia) which can affect medication adherence. This can be resolved by using 3D printed dosage forms with embossing designs on them which can indicate the time of administration, date, and/or weekday for administration, customizable to each patient (141).

\section{Tending to the Visually Impaired}

Visual impairment affects about 285 million people worldwide and this leads to several concerns when it comes to medication and treatment, especially in the older population who are dependent on multiple medications. This leads to poor medication adherence and treatment management which would eventually lead to therapeutic inefficiency. Awad et al. used SLA to fabricate orally disintegrating tablets well suited for visually challenged patients. These printlets composed of Braille and Moon patterns on their surface which can enable patients to identify the medication when extracted from their package. Tablets of various shapes were developed which offered added information like medication indication or dosing regimen. This innovative concept can aid the treatment of visually impaired patients greatly by improving medication adherence and reducing medication errors (142).

\section{$3 D$ Printing in a Clinical Setting}

Studies have shown that 3D printed dosage forms have been well accepted by patients. Most individuals held positive views on medicines printed by 3D printers $(138,141,143)$. In the near future, this technology can have a massive role to 
play in hospitals and hospital pharmacies to dispense personalized pharmaceutical products. This involves complete diagnosis and fabrication of dosage forms that will be most suitable to patients. In a possible setup, a patient upon his/her arrival at the hospital would undergo diagnosis to identify and analyze his/her medical condition. Other factors will be taken into account like the person's age, body weight, presence of other conditions, treatment history, and lifestyle. The genetic aspects would also be taken into consideration through body fluid tests. All of this data could be combined to form the individual's profile which would contain all necessary details. Based on this profile, a treatment plan could be identified, and the patient would receive a prescription which is solely based on his/her needs. The most adequate dosage forms could then be identified using various databases and artificial intelligence platforms. The dosage form could then be printed using a 3D printer present in the hospital, through CAD software. This medication, after suitable quality control, can then be given to the patient. The patient is then followed up and feedback obtained. With technological advances in testing, data processing, and $3 \mathrm{D}$ printing, this entire process can be made faster which can prove to be promising in a clinical setting.

\section{CHALLENGES}

Despite its immense benefit in the pharmaceutical sector, 3D printing possesses several challenges. They are mostly regarding the technology, manufacture of dosage forms, safety, quality control, regulatory aspects, and their implementation in clinical pharmacy.

\section{Technology}

The technological limitation of each type of 3D printer has been mentioned above. The nozzle-based systems might suffer from clogging of the nozzle whereas thermal and laserbased systems might suffer from degradation of the API employed. A major challenge is the drug-excipient incompatibility which has to be addressed. Also, structural and surface imperfections may arise in the final product which has to be addressed by optimizing various manufacturing parameters.

\section{Materials Used}

Another challenge may be the availability of suitable materials of appropriate grades for 3D printing, for example, suitable polymers for FDM like HPC, PVA, and Eudragit and resins for SLA like polyethylene glycol di-acrylate and poly(ethylene glycol) di-methacrylate. These materials, apart from being compatible with the drug, must be biocompatible, biodegradable and suitable for manufacturing using 3D printing (22). Also, they must not generate toxic substances while processing.

\section{Safety Aspects}

Safety considerations must also be addressed. There is a possibility of emission of toxic airborne matter resulting from the heating, extrusion or fusion of certain materials which can act as respiratory or skin irritants. Hence, adequate safety measures must be taken and standard operating guidelines must be followed to minimize the hazardous exposure (144).

\section{Clinical Pharmacy Practice}

Integrating $3 \mathrm{D}$ printing into hospitals also presents several challenges. First of all, it requires highly skilled technical operators on site to handle the technical aspects, which might seem impractical. Another challenge is quality control of the printed dosage forms and techniques for this must be developed which must be non-destructive and feasible. This has already been addressed by involving various process analytical technologies (PAT) to monitor the quality. A PAT model involving near-infrared spectroscopy and Raman confocal microscopy was demonstrated which showed high accuracy in measuring the drug concentration and drug distribution in tablets and oral films (145).

Also, financial aspects must be considered, as establishing $3 \mathrm{D}$ printers in hospitals might be expensive. Packaging and labeling requirements must also be considered to meet the requirements of personalized medicine in a clinical setting. Furthermore, since every printing platform mentioned above has their pros and cons, it cannot be concluded as to which type of printer can be ideal for a hospital setting. Hence, further technological developments are necessary to bring in "the perfect 3D printer" for clinical use, which must be fast, user friendly, and cost-effective with a good resolution.

\section{Regulatory Aspects}

Another major obstacle in using this technology for the manufacture of pharmaceutical products is the lack of regulatory framework. In 2017, FDA issued the guidance comprising of regulatory requirements for the manufacturing of medical devices (146). So far, there are several FDA approved $3 \mathrm{D}$ printed medical devices in the market, but only one FDA-approved 3D printed pharmaceutical product (Spritam) is available. Unfortunately, guidelines for $3 \mathrm{D}$ printed dosage form manufacturing have not been issued by any regulatory authority. Furthermore, it remains unclear if the regulatory approval will apply to only the final product or to a set of requirements which will apply to all components and stages of designing and manufacturing of a product (144).

In the present scenario, a tablet containing more than one drug would be considered as a new combination drug formulation, according to the FDA, and would require extensive clinical trials to guarantee patient safety and efficacy. Also, every location employing a 3D printer for producing and dispensing pharmaceutical products would have to be certified as a "Good Manufacturing Practice" (GMP) facility (23). Hence, appropriate regulatory guidelines must be developed regarding the manufacture and dispensing of pharmaceutical products.

\section{Anti-counterfeiting}

Another major challenge with the advent of 3D printing is that, due to the lack of regulations, there can be a rise in counterfeit medications. These fraudulent medicines often do not meet the minimum quality requirements. Also, they could 
be obtained easily, at low costs. These medications are not safe for consumption and may bring about harm and additional complications to the people. According to the World Health Organization, $10.5 \%$ of low and middle income countries are inflicted with low-grade and falsified medicines which cost an approximate of US $\$ 30.5$ billion annually. Hence, adequate measures to prevent these fraudulent activities must be taken.

One study developed a novel track and trace anticounterfeit measure for $3 \mathrm{D}$ printed medicines, using inkjet printing. Quick response (QR) codes and data matrices were printed on the surface of the 3D printed printlets, which could be scanned using a smartphone. They were designed to encode tailored information related to the drug product, patient and prescriber. Further, by increasing the number of excipients and coloring agents within the inks used, the randomized code could cover millions of combinations assisting improved tracking and authentication system of pharmaceutical products (147).

\section{D BIO-PRINTING}

Yet another wide application of 3D printing is 3D bioprinting. 3D bio-printing involves dispensing cell-loaded biomaterials for the fabrication of complex functional living tissues or organs. It has been used in regenerative medicine to construct tissues like skin, bone, and cartilage. Hence, a different technical approach compatible with the deposition of living cells becomes necessary. Some advantages include scalability, accurate control of cell deposition, high resolution, personalization, and cost-effectiveness (148). Bio-inks are formulations that compose of cells and may include biomaterials and biologically active components. The cells may be in various forms and environments and might even be seeded into various carriers.

Cartilage structures were fabricated using nano-fibrillated cellulose having shear thinning properties and alginate with a good cross-linking ability. These proved to be non-cytotoxic and had good cell viability (149). Bioactive bone scaffolds to enhance bone regeneration were developed, which were based on poly-lactic acid. These were coated with gels comprising of mucic acid. This coating improved their physicochemical properties and favored osteoblast differentiation (150). Another team fabricated small diameter blood vessels with two distinct cell layers using 3D bio-printing. Good cell proliferation and angiogenesis were observed in the blood vessels (151). 3D bio-printing has also been used in the fabrication of neuronal tissues (152). Researchers have also successfully printed a heart using human cells, complete with blood vessels, ventricles, and chambers (153). Despite its benefits, bioprinting does face several problems like cell viability and the control of cell proliferation. The materials and cells employed must also be compatible with the printing process. Another major concern of bio-printing is regarding its safety. The materials used should be biocompatible and safe (154).

\section{CONCLUSION}

The rapid advancement of $3 \mathrm{D}$ printing technologies could move the pharmaceutical production from mass manufacture to on-demand personalized dosage forms which would provide patients with more safe and effective medicines. Its potential to transform the conventional pharmacy practice could be pivotal to the healthcare system. Apart from its clinical use, this technology can also be employed in the industries to develop dosage forms with complex shapes and release profiles. The approval of Spritam by the FDA is a remarkable milestone in the field of $3 \mathrm{D}$ printing and there has been an abundance of promising research ever since. The greatest advantages of using 3D printing in the pharmaceutical sector include fast manufacturing speed, cost-effectiveness, and formulation flexibility. Furthermore, the pros and cons of various platforms must be analyzed to develop a 3D printer ideal for a hospital setting.

Despite its benefits and considerable progress, the use of this technology to fabricate pharmaceutical products still remains in its infancy. This is due to the various challenges faced, mainly the technical, quality control, and regulatory aspects. Moreover, relevant regulatory guidelines have to be formulated pertaining to the use of this technology in a clinical setting. Once these challenges are addressed, there will be no looking back, and the pharmaceutical sector can completely embrace the technology. It can then be possible to look at a smart future with personalized medicine which can revolutionize the healthcare system.

\section{FUNDING}

Open access funding provided by Manipal Academy of Higher Education, Manipal.

Open Access This article is licensed under a Creative Commons Attribution 4.0 International License, which permits use, sharing, adaptation, distribution and reproduction in any medium or format, as long as you give appropriate credit to the original author(s) and the source, provide a link to the Creative Commons licence, and indicate if changes were made. The images or other third party material in this article are included in the article's Creative Commons licence, unless indicated otherwise in a credit line to the material. If material is not included in the article's Creative Commons licence and your intended use is not permitted by statutory regulation or exceeds the permitted use, you will need to obtain permission directly from the copyright holder. To view a copy of this licence, visit http://creativecommons.org/licenses/by/4.0/.

\section{REFERENCES}

1. Litman T. Personalized medicine - concepts, technologies, and applications in inflammatory skin diseases. Apmis. 2019;127(5):386-424.

2. Žitnik IP, Zerne D, Mancini I, Simi L, Pazzagli M, Di Resta C, et al. Personalized laboratory medicine: a patient-centered future approach. Clin Chem Lab Med. 2018;56(12):1981-91.

3. Florence AT, Siepmann J. Dosage forms for personlaized medicine: from the simple to the complex. In: Modern pharmaceutics Vol 2 - applications and advances. 5th ed. Informa Healthcare USA, Inc.; 2009. p. 493.

4. Mathur S, Sutton J. Personalized medicine could transform healthcare (review). Biomed Reports. 2017;7(1):3-5. 
5. Yao R, Xu G, Mao S, Yang H, Sang X, Sun W, et al. Threedimensional printing : review of application in medicine and hepatic surgery. Cancer Biol Med. 2016;13(4):443-51.

6. Chen G, Xu Y, Kwok PCL, Kang L. Pharmaceutical applications of 3D printing. Addit Manuf. 2020;34:101209. https:// doi.org/10.1016/j.addma.2020.101209.

7. Pandey M, Choudhury H, Fern JLC, Kee ATK, Kou J, Jing JLJ, et al. 3D printing for oral drug delivery: a new tool to customize drug delivery. Drug Deliv Transl Res. 2020;10(4):986-1001.

8. Trenfield SJ, Awad A, Goyanes A, Gaisford S, Basit AW. 3D printing pharmaceuticals: drug development to frontline care. Trend Pharmacol Sci. 2018;39:440-51.

9. Savini A, Savini GG. A short history of 3D printing, a technological revolution just started. 4th IEEE Reg 8 Conf Hist Electrotechnol. 2015. https://doi.org/10.1109/ HISTELCON.2015.7307314.

10. Su A, Al'Aref SJ. History of 3D printing. 3D printing applications in cardiovascular medicine. 2018. pp. 1-10. Available from: https://doi.org/10.1016/B978-0-12-8039175.00001-8, 2018

11. Prasad LK, Smyth H. 3D printing technologies for drug delivery: a review. Drug Dev Ind Pharm. 2016;42(7):1019-31.

12. Jiménez M, Romero L, Domínguez IA, Espinosa MDM, Domínguez M. Additive manufacturing technologies: an overview about 3D printing methods and future prospects. Complexity. 2019;2019.Article ID: 9656938.

13. Water JJ, Bohr A, Boetker J, Aho J, Sandler N. Threedimensional printing of drug-eluting implants: preparation of an antimicrobial polylactide feedstock material. J Pharm Sci. 2015;104(3):1099-7.

14. Ballard DH, Trace AP, Ali S, Hodgdon T, Zygmont ME, DeBenedectis CM, et al. Clinical applications of 3D printing: primer for radiologists. Acad Radiol. 2018;25(1):52-65. Available from: https://doi.org/10.1016/j.acra.2017.08.004, 2018.

15. Trenfield SJ, Madla CM, Basit AW, Gaisford S. Binder jet printing in pharmaceutical manufacturing. AAPS Adv Pharm Sci Ser. 2018;31:41-54

16. Goole J, Amighi K. 3D printing in pharmaceutics: a new tool for designing customized drug delivery systems. Int J Pharm. 2016;499(1-2):376-94.

17. Kotta S, Nair A, Alsabeelah N. 3D printing technology in drug delivery: recent progress and application. Curr Pharm Des. 2018;24(42):5039-48.

18. Azizi Machekposhti S, Mohaved S, Narayan RJ. Inkjet dispensing technologies: recent advances for novel drug discovery. Expert Opin Drug Discov. 2019;14(2):101-113. Available from: https://doi.org/10.1080/17460441.2019.1567489

19. Daly R, Harrington TS, Martin GD, Hutchings IM. Inkjet printing for pharmaceutics - a review of research and manufacturing. Int J Pharm. 2015;494(2):554-567. Available from: https://doi.org/10.1016/j.ijpharm.2015.03.017

20. Ic IN, Giridhar A, Taylor LS, Nagy ZK, Reklaitis GV. Dropwise additive manufacturing of pharmaceutical products for melt-based dosage forms. J Pharm Sci. 2015;104(5):1641-9.

21. Alomari M, Mohamed FH, Basit AW, Gaisford S. Personalised dosing: printing a dose of one's own medicine. Int J Pharm 2015;494(2):56-577. Available from: https://doi.org/10.1016/ j.ijpharm.2014.12.006

22. Lamichhane S, Bashyal S, Keum T, Noh G, Seo JE, Bastola R, et al. Complex formulations, simple techniques: can 3D printing technology be the midas touch in pharmaceutical industry? Asian J Pharm Sci. 2019;14:465-79.

23. F G, Velez A. 3D pharming: direct printing of personalized pharmaceutical tablets. Polym Sci 2016;2(1):1-10.

24. Vadodaria S, Mills T. Jetting-based 3D printing of edible materials. Food Hydrocoll. 2020;106:105857. Available from: https://doi.org/10.1016/j.foodhyd.2020.105857

25. Kollamaram G, Faucher A, Croker DM, Walker GM. Valvejet technology for the production of a personalised fixed dose combination of ramipril and glimepiride: an investigative study on the stability of ramipril. Pharm Res. 2018;35(9):181 pages 15 .

26. Kollamaram G, Hopkins SC, Glowacki BA, Croker DM, Walker GM. Inkjet printing of paracetamol and indomethacin using electromagnetic technology: rheological compatibility and polymorphic selectivity. Eur J Pharm Sci. 2018;115:248257. Available from: https://doi.org/10.1016/j.ejps.2018.01.036

27. Ehtezazi T, Dempster NM, Martin GD, Hoath SD, Hutchings IM. Development of high-throughput glass inkjet devices for pharmaceutical applications. J Pharm Sci. 2014;103(11):37333742. Available from: https://doi.org/10.1002/jps.24192

28. Clark EA, Alexander MR, Irvine DJ, Roberts CJ, Wallace MJ, Sharpe S, et al. 3D printing of tablets using inkjet with UV photoinitiation. Int J Pharm. 2017;529(1-2):523-530. Available from: https://doi.org/10.1016/j.ijpharm.2017.06.085

29. Musazzi UM, Khalid GM, Selmin F, Minghetti P, Cilurzo F. Trends in the production methods of orodispersible films. Int $\mathbf{J}$ Pharm. 2020;576:118963. Available from: https://doi.org/ 10.1016/j.ijpharm.2019.118963, 2020.

30. Thabet Y, Lunter D, Breitkreutz J. Continuous inkjet printing of enalapril maleate onto orodispersible film formulations. Int J Pharm. 2018;546(1-2):180-187. Available from: https:// doi.org/10.1016/j.ijpharm.2018.04.064.

31. Vakili H, Nyman JO, Genina N, Preis M, Sandler N. Application of a colorimetric technique in quality control for printed pediatric orodispersible drug delivery systems containing propranolol hydrochloride. Int J Pharm. 2016;511(1):606618. Available from: https://doi.org/10.1016/ j.ijpharm.2016.07.032

32. Alomari M, Vuddanda PR, Trenfield SJ, Dodoo CC, Velaga S, Basit AW, et al. Printing T3 and T4 oral drug combinations as a novel strategy for hypothyroidism. Int J Pharm. 2018;549(12):363-9.

33. Eleftheriadis GK, Katsiotis CS, Andreadis DA, Tzetzis D, Ritzoulis C, Bouropoulos $\mathrm{N}$, et al. Inkjet printing of a thermolabile model drug onto FDM-printed substrates: formulation and evaluation. Drug Dev Ind Pharm. 2020;46(8):12531264. Available from: https://doi.org/10.1080/ 03639045.2020.1788062

34. Palo M, Kogermann K, Laidmäe I, Meos A, Preis M, Heinämäki J, et al. Development of oromucosal dosage forms by combining electrospinning and inkjet printing. Mol Pharm. 2017;14(3):808-20.

35. Iftimi LD, Edinger M, Bar-Shalom D, Rantanen J, Genina N. Edible solid foams as porous substrates for inkjet-printable pharmaceuticals. Eur J Pharm Biopharm. 2019;136:38-47. Available from: https://doi.org/10.1016/j.ejpb.2019.01.004

36. Montenegro-Nicolini M, Reyes PE, Jara MO, Vuddanda PR, Neira-Carrillo A, Butto N, et al. The effect of inkjet printing over polymeric films as potential buccal biologics delivery systems. AAPS PharmSciTech. 2018;19(8):3376-87.

37. Montenegro-Nicolini M, Miranda V, Morales JO. Inkjet printing of proteins: an experimental approach. AAPS J. 2017;19(1):234-243. Available from: https://doi.org/10.1208/ s12248-016-9997-8

38. Arshad MS, Shahzad A, Abbas N, AlAsiri A, Hussain A, Kucuk I, et al. Preparation and characterization of indomethacin loaded films by piezoelectric inkjet printing: a personalized medication approach. Pharm Dev Technol. 2020;25(2):197-205. Available from: https://doi.org/10.1080/ 10837450.2019.1684520

39. Pere CPP, Economidou SN, Lall G, Ziraud C, Boateng JS, Alexander BD, et al. 3D printed microneedles for insulin skin delivery. Int J Pharm. 2018;544(2):425-32.

40. Boehm RD, Miller PR, Daniels J, Stafslien S, Narayan RJ. Inkjet printing for pharmaceutical applications. Mater Today. 2014;17(5):247-252. Available from: https://doi.org/10.1016/ j.mattod.2014.04.027

41. Boehm RD, Daniels J, Stafslien S, Nasir A, Lefebvre J, Narayan RJ. Polyglycolic acid microneedles modified with inkjet-deposited antifungal coatings. Biointerphases. 2015;10(1):011004

42. Purohit HS, Wallace C, Giridhar A, Taylor LS, Nagy ZK, Gintaras V. Dropwise additive manufacturing of pharmaceutical products for amorphous and self emulsifying drug delivery systems. Int J Pharm. 2017;524(1-2):424-432. Available from: https://doi.org/10.1016/j.ijpharm.2017.04.003

43. Clark EA, Alexander MR, Irvine DJ, Roberts CJ, Wallace MJ, Yoo J, et al. Making tablets for delivery of poorly soluble drugs 
using photoinitiated 3D inkjet printing. Int $\mathrm{J}$ Pharm. 2020;578:118805. Available from: https://doi.org/10.1016/ j.ijpharm.2019.118805

44. Cader HK, Rance GA, Alexander MR, Gonçalves AD, Roberts CJ, Tuck CJ, et al. Water-based 3D inkjet printing of an oral pharmaceutical dosage form. Int $\mathrm{J}$ Pharm. 2019;564:359-368. Available from: https://doi.org/10.1016/ j.ijpharm.2019.04.026

45. López-iglesias C, Casielles AM, Altay A, Bettini R, Alvarezlorenzo C, García-gonzález CA. From the printer to the lungs: inkjet-printed aerogel particles for pulmonary delivery. Chem Eng J. 2019;357:559-566. Available from: https://doi.org/ 10.1016/j.cej.2018.09.159

46. Wickstrm H, Hilgert E, Nyman JO, Desai D, Karaman DŞ, De Beer T, et al. Inkjet printing of drug-loaded mesoporous silica nanoparticles - a platform for drug development. Molecules. 2017;22(11):1-20.

47. Lee KJ, Kang A, Delfino JJ, West TG, Chetty D, Monkhouse DC, et al. Evaluation of critical formulation factors in the development of a rapidly dispersing captopril oral dosage form. Drug Dev Ind Pharm. 2003;29(9):967-79.

48. Tian P, Yang F, Yu LP, Lin MM, Lin W, Lin QF, et al. Applications of excipients in the field of 3D printed pharmaceuticals. Drug Dev Ind Pharm. 2019;45(6):905-913. Available from: https://doi.org/10.1080/03639045.2019.1576723

49. Infanger S, Haemmerli A, Iliev S, Baier A, Stoyanov E, Quodbach J. Powder bed 3D-printing of highly loaded drug delivery devices with hydroxypropyl cellulose as solid binder. Int J Pharm. 2019;555:198-206. Available from: https://doi.org/ 10.1016/j.ijpharm.2018.11.048

50. Wilts EM, Ma D, Bai Y, Williams CB, Long TE. Comparison of linear and 4-arm star poly(vinyl pyrrolidone) for aqueous binder jetting additive manufacturing of personalized dosage tablets. ACS Appl Mater Interfaces. 2019;11(27):23938423947.

51. Katstra WE, Palazzolo RD, Rowe CW, Giritlioglu B, Teung P, Cima MJ. Oral dosage forms fabricated by three dimensional printing(TM). J Control Release. 2000;66(1):1-9.

52. Wang CC, Tejwani MR, Roach WJ, Kay JL, Yoo J, Surprenant HL, et al. Development of near zero-order release dosage forms using three-dimensional printing (3-DP ${ }^{\mathrm{TM}}$ ) technology. Drug Dev Ind Pharm. 2006;32(3):367-76.

53. Yu DG, Branford-White C, Ma ZH, Zhu LM, Li XY, Yang $\mathrm{XL}$. Novel drug delivery devices for providing linear release profiles fabricated by 3DP. Int J Pharm. 2009;370(1-2):160-6.

54. Shi K, Tan DK, Nokhodchi A, Maniruzzaman M. Drop-onpowder 3D printing of tablets with an anti-cancer drug, 5fluorouracil. Pharmaceutics. 2019;11(4):1-10.

55. Sen K, Manchanda A, Mehta T, Ma AWK, Chaudhuri B. Formulation design for inkjet-based 3D printed tablets. Int $\mathrm{J}$ Pharm. 2020;584:119430. Available from: https://doi.org/ 10.1016/j.ijpharm.2020.119430

56. Awad A, Tren SJ, Gaisford S, Basit AW. 3D printed medicines : a new branch of digital healthcare. Int $\mathrm{J}$ Pharm $\mathrm{J}$. 2018;548:586-96.

57. Shaqour B, Samaro A, Verleije B, Beyers K, Vervaet C. Production of drug delivery systems using fused filament fabrication: a systematic review. Pharmaceutics. 2020;12(6):517 Pages 16.

58. Araújo MRP, Sa-barreto LL, Gratieri T, Gelfuso GM, Cunhafilho $M$. The digital pharmacies era: how 3D printing technology using fused deposition modeling can become a reality? Pharmaceutics. 2019;11(3):128.

59. Fanous M, Gold S, Muller S, Hirsch S, Ogorka J. Simplification of fused deposition modeling 3D-printing paradigm : feasibility of 1-step direct powder printing for immediate release dosage form production. Int J Pharm. 2020;578(November 2019):119124. Available from: https://doi.org/10.1016/ j.ijpharm.2020.119124

60. Jie J, Awad A, Martorana A, Gaisford S, Stoyanov E. 3D printed opioid medicines with alcohol-resistant and abusedeterrent properties. Int J Pharm. 2020;579:119169. Available from: https://doi.org/10.1016/j.ijpharm.2020.119169

61. Kurek M, Czech A, Gawlak K, Knapik-kowalczuk J, Paluch $\mathrm{M}$, Jachowicz R, et al. Speed it up, slow it down... An issue of bicalutamide release from 3D printed tablets. Eur J Pharm Sci. 2020;143:105169.

62. Matijašić G, Gretić M, Kezerić K, Petanjek J, Vukelić E. Preparation of filaments and the 3D printing of dronedarone $\mathrm{HCl}$ tablets for treating cardiac arrhythmias. AAPS PharmSciTech. 2019;20(8):1-13.

63. Nukala PK, Palekar S, Patki M, Patel K. Abuse deterrent immediate release egg-shaped tablet (Egglets) using 3D printing technology: quality by design to optimize drug release and extraction. AAPS PharmSciTech. 2019;20(2):80.

64. Öblom H, Zhang J, Pimparade M, Speer I, Preis M, Repka M, et al. 3D-printed isoniazid tablets for the treatment and prevention of tuberculosis - personalized dosing and drug release. AAPS PharmSciTech. 2019;20(2):52 Pages 13.

65. Hattori Y, Kubota S, Otsuka M. Pharmaceutical evaluation of matrix tablets prepared using a fused deposition modelling type three-dimensional printer - effect of geometrical internal microstructural factors on drug release from enteric-polymer tablets containing rebamipide. J Pharm Pharmacol. 2020;72(6):787-97.

66. Ibrahim M, Barnes M, Mcmillin R, Cook DW, Smith S, Halquist $\mathrm{M}$, et al. 3D printing of metformin $\mathrm{HCl}$ PVA tablets by fused deposition modeling: drug loading, tablet design, and dissolution studies. AAPS PharmSciTech. 2019;20:195 Pages 11.

67. Wei C, Solanki NG, Vasoya JM, Shah A V., Serajuddin ATM. Development of 3D printed tablets by fused deposition modeling using polyvinyl alcohol as polymeric matrix for rapid drug release. J Pharm Sci. 2020;109(4):1558-1572. Available from: https://doi.org/10.1016/j.xphs.2020.01.015

68. Gioumouxouzis CI, Tzimtzimis E, Katsamenis OL, Dourou A, Markopoulou C, Bouropoulos N, et al. Fabrication of an osmotic 3D printed solid dosage form for controlled release of active pharmaceutical ingredients. Eur J Pharm Sci. 2020;143:105176. Available from: https://doi.org/10.1016/ j.ejps.2019.105176

69. Sadia M, Isreb A, Abbadi I, Isreb M, Aziz D, Selo A, et al. From 'fixed dose combinations' to 'a dynamic dose combiner': 3D printed bi-layer antihypertensive tablets. Eur J Pharm Sci. 2018;123:484-94.

70. Gioumouxouzis CI, Baklavaridis A, Katsamenis OL, Markopoulou CK, Bouropoulos N, Tzetzis D, et al. A 3D printed bilayer oral solid dosage form combining metformin for prolonged and glimepiride for immediate drug delivery. Eur J Pharm Sci. 2018;120:40-52.

71. Vo AQ, Zhang J, Nyavanandi D, Bandari S, Repka MA. Hot melt extrusion paired fused deposition modeling $3 \mathrm{D}$ printing to develop hydroxypropyl cellulose based floating tablets of cinnarizine. Carbohydr Polym. 2020;246:116519. Available from: https://doi.org/10.1016/j.carbpol.2020.116519

72. Giri BR, Song ES, Kwon J, Lee JH, Park JB, Kim DW. Fabrication of intragastric floating, controlled release 3D printed theophylline tablets using hot-melt extrusion and fused deposition modeling. Pharmaceutics. 2020;12(1):77 Pages 16.

73. Shin S, Kim TH, Jeong SW, Chung SE, Lee DY, Kim DH, et al. Development of a gastroretentive delivery system for acyclovir by $3 \mathrm{D}$ printing technology and its in vivo pharmacokinetic evaluation in Beagle dogs. PLoS One. 2019;14(5):1-17.

74. Dumpa NR, Bandari S, Repka MA. Novel gastroretentive floating pulsatile drug delivery system produced via hot-melt extrusion and fused deposition modeling 3D printing. Pharmaceutics. 2020;12(1):52 Pages 13.

75. Jeong HM, Weon KY, Shin BS, Shin S. 3D-printed gastroretentive sustained release drug delivery system by applying design of experiment approach. Molecules. 2020;25(10):2330.

76. Charoenying $\mathrm{T}$, Patrojanasophon $\mathrm{P}$, Ngawhirunpat $\mathrm{T}$, Rojanarata T, Akkaramongkolporn P, Opanasopit P. Fabrication of floating capsule-in- 3D-printed devices as gastroretentive delivery systems of amoxicillin. J Drug Deliv Sci Technol. 2020;55:101393. Available from: https://doi.org/ 10.1016/j.jddst.2019.101393

77. Fu J, Yin H, Yu X, Xie C, Jiang H, Jin Y, et al. Combination of 3D printing technologies and compressed tablets for preparation of riboflavin floating tablet-in-device (TiD) systems. Int $\mathrm{J}$ 
Pharm. 2018;549(1-2):370-379. Available from: https://doi.org/ 10.1016/j.ijpharm.2018.08.011

78. Tan DK, Maniruzzaman M, Nokhodchi A. Development and optimisation of novel polymeric compositions for sustained release theophylline. Polymers (Basel). 2019;12(1):1-18.

79. Ehtezazi T, Algellay M, Islam Y, Roberts M, Dempster NM, Sarker SD. The application of 3D printing in the formulation of multilayered fast dissolving oral films. J Pharm Sci. 2018;107(4):1076-1085. Available from: https://doi.org/ 10.1016/j.xphs.2017.11.019

80. Eleftheriadis GK, Ritzoulis C, Bouropoulos N, Tzetzis D, Andreadis DA, Boetker $\mathrm{J}$, et al. Unidirectional drug release from 3D printed mucoadhesive buccal films using FDM technology: in vitro and ex vivo evaluation. Eur $\mathrm{J}$ Pharm Biopharm. 2019;144:180-192. Available from: https://doi.org/ 10.1016/j.ejpb.2019.09.018

81. Luzuriaga MA, Berry DR, Reagan JC, Smaldone RA, Gassensmith JJ. Biodegradable 3D printed polymer microneedles for transdermal drug delivery. Lab Chip. 2018;18(8):1223-30.

82. Tagami T, Hayashi N, Sakai N, Ozeki T. 3D printing of unique water-soluble polymer-based suppository shell for controlled drug release. Int J Pharm. 2019;568:118494. Available from: https://doi.org/10.1016/j.ijpharm.2019.118494

83. Qamar N, Abbas N, Irfan M, Hussain A, Sohail M. Personalized $3 \mathrm{D}$ printed ciprofloxacin impregnated meshes for the management of hernia Abstract : J Drug Deliv Sci Technol. 2019;53(101164).

84. Jiang H, Fu J, Li M, Wang S, Zhuang B, Sun H, et al. 3Dprinted wearable personalized orthodontic retainers for sustained release of clonidine hydrochloride. AAPS PharmSciTech. 2019;20(7):1-10.

85. Goyanes A, Det-amornrat U, Wang J, Basit AW, Gaisford S. $3 \mathrm{D}$ scanning and $3 \mathrm{D}$ printing as innovative technologies for fabricating personalized topical drug delivery systems. J Control Release. 2016;234:41-48. Available from: https:// doi.org/10.1016/j.jconrel.2016.05.034

86. $\mathrm{Fu} \mathrm{J}, \mathrm{Yu} \mathrm{X}$, Jin $\mathrm{Y}$. 3D printing of vaginal rings with personalized shapes for controlled release of progesterone. Int J Pharm. 2018;539(1-2):75-82. Available from: https:// doi.org/10.1016/j.ijpharm.2018.01.036

87. Nober C, Manini G, Carlier E, Raquez JM, Benali S, Dubois P, et al. Feasibility study into the potential use of fused-deposition modeling to manufacture 3D-printed enteric capsules in compounding pharmacies. Int J Pharm. 2019;569:118581. Available from: https://doi.org/10.1016/j.ijpharm.2019.118581

88. Matijašić G, Gretić M, Vinčić J, Poropat A, Cuculić L, Rahelić T. Design and 3D printing of multi-compartmental PVA capsules for drug delivery. J Drug Deliv Sci Technol. 2019;52:677-86.

89. Lamichhane S, Park J, Sohn DH, Lee S. Customized novel design of $3 \mathrm{D}$ printed pregabalin tablets for intra-gastric floating and controlled release using fused deposition modeling. Pharmaceutics. 2019;11(11):564 Pages 14.

90. Smith D, Kapoor Y, Hermans A, Nofsinger R, Kesisoglou F, Gustafson TP, et al. 3D printed capsules for quantitative regional absorption studies in the GI tract. Int $\mathrm{J}$ Pharm. 2018;550(1-2):418-428. Available from: https://doi.org/10.1016/ j.ijpharm.2018.08.055

91. Charoo NA, Barakh Ali SF, Mohamed EM, Kuttolamadom MA, Ozkan T, Khan MA, et al. Selective laser sintering 3D printing-an overview of the technology and pharmaceutical applications. Drug Dev Ind Pharm. 2020;46(6):869-877. Available from: https://doi.org/10.1080/03639045.2020.1764027

92. Fina F, Goyanes A, Gaisford S, Basit AW. Selective laser sintering (SLS) 3D printing of medicines. Int J Pharm. 2017;529(1-2):285-293. Available from: https://doi.org/ 10.1016/j.ijpharm.2017.06.082

93. Cheah CM, Leong KF, Chua CK, Low KH, Quek HS. Characterization of microfeatures in selective laser sintered drug delivery devices. Proc Inst Mech Eng Part H J Eng Med. 2002;216(6):369-83.

94. Leong KF, Chua CK, Gui WS, Verani. Building porous biopolymeric microstructures for controlled drug delivery devices using selective laser sintering. Int $\mathrm{J}$ Adv Manuf Technol. 2006;31(5-6):483-9.

95. Fina F, Madla CM, Goyanes A, Zhang J, Gaisford S, Basit AW. Fabricating 3D printed orally disintegrating printlets using selective laser sintering. Int J Pharm. 2018;541(12):101-107. Available from: https://doi.org/10.1016/ j.ijpharm.2018.02.015

96. Allahham N, Fina F, Marcuta C, Kraschew L, Mohr W, Gaisford S, et al. Selective laser sintering 3D printing of orally disintegrating printlets containing ondansetron. Pharmaceutics. 2020;12(2):1-13.

97. Awad A, Fina F, Trenfield SJ, Patel P, Goyanes A, Gaisford S, et al. 3D printed pellets (Miniprintlets): A novel, multi-drug, controlled release platform technology. Pharmaceutics. 2019;11(4):148 Pages 17.

98. Fina F, Goyanes A, Madla CM, Awad A, Trenfield SJ, Kuek $\mathrm{JM}$, et al. 3D printing of drug-loaded gyroid lattices using selective laser sintering. Int J Pharm. 2018;547(1-2):44-52. Available from: https://doi.org/10.1016/j.ijpharm.2018.05.044

99. Martinez PR, Basit AW, Gaisford S. The history, developments and opportunities of stereolithography. In: 3D Printing of Pharmaceuticals. 2018. pp. 55-79.

100. Xu X, Robles-martinez P, Madla CM, Joubert F, Goyanes A, Basit AW, et al. Stereolithography (SLA) 3D printing of an antihypertensive polyprintlet: case study of an unexpected photopolymer-drug reaction. Addit Manuf. 2020;33:101071. Available from: https://doi.org/10.1016/j.addma.2020.101071

101. Wang J, Goyanes A, Gaisford S, Basit AW. Stereolithographic (SLA) 3D printing of oral modified-release dosage forms. Int $\mathrm{J}$ Pharm. 2016; Available from: https://doi.org/10.1016/ j.ijpharm.2016.03.016.

102. Martinez PR, Goyanes A, Basit AW, Gaisford S. Influence of geometry on the drug release profiles of stereolithographic (SLA) 3D-printed tablets. AAPS PharmSciTech. 2018;19(8):3355-61.

103. Martinez PR, Goyanes A, Basit AW, Gaisford S. Fabrication of drug-loaded hydrogels with stereolithographic $3 \mathrm{D}$ printing. Int J Pharm. 2017;532(1):313-317. Available from: https://doi.org/ 10.1016/j.ijpharm.2017.09.003

104. Karakurt I. Stereolithography (SLA) 3D printing of ascorbic acid loaded hydrogels : a controlled release study. Int J Pharm. 2020:584:119428.

105. Uddin JM, Scoutaris N, Economidou SN, Giraud C, Chowdhry BZ, Donnelly RF, et al. 3D printed microneedles for anticancer therapy of skin tumours. Mater Sci Eng C. 2020;107:110248. Available from: https://doi.org/10.1016/j.msec.2019.110248

106. Konasch J, Riess A, Mau R, Teske M, Rekowska N, Eickner T, et al. A novel hybrid additive manufacturing process for drug delivery systems with locally incorporated drug depots. Pharmaceutics. 2019;11(12):661 Pages 14.

107. Forouzandeh F, Ahamed NN, Hsu M, Walton JP, Frisina RD, Borkholder DA. A 3D-printed modular microreservoir for drug delivery. Micromachines. 2020;11(7):648 Pages 17.

108. Azad MA, Olawuni D, Kimbell G, Badruddoza AZM, Hossain MS, Sultana T. Polymers for extrusion-based 3D printing of pharmaceuticals: a holistic materials-process perspective. Pharmaceutics. 2020;12:1-34 Pages 34.

109. El Aita I, Breitkreutz J, Quodbach J. On-demand manufacturing of immediate release levetiracetam tablets using pressureassisted microsyringe printing. Eur J Pharm Biopharm. 2019;134:29-36. Available from: https://doi.org/10.1016/ j.ejpb.2018.11.008.

110. Aita I El, Breitkreutz J, Quodbach J. Investigation of semisolid formulations for $3 \mathrm{D}$ printing of drugs after prolonged storage to mimic real-life applications. Eur J Pharm Sci. 2020;146:105266. Available from: https://doi.org/10.1016/ j.ejps.2020.105266.

111. Wen H, He B, Wang H, Chen F, Li P, Cui M, et al. Structurebased gastro-retentive and controlled-release drug delivery with novel 3D printing. AAPS PharmSciTech. 2019;20(2):68 Pages 12

112. Tagami T, Yoshimura N, Goto E, Noda T, Ozeki T. Fabrication of muco-adhesive oral films by the $3 \mathrm{D}$ printing of hydroxypropyl methylcellulose-based catechin-loaded formulations. Biol Pharm Bull. 2019;42(11):1898-905. 
113. Eleftheriadis GK, Monou PK, Bouropoulos N, Boetker J, Rantanen $\mathrm{J}$, Jacobsen $\mathrm{J}$, et al. Fabrication of mucoadhesive buccal films for local administration of ketoprofen and lidocaine hydrochloride by combining fused deposition modeling and inkjet printing. J Pharm Sci. 2020;109(9):2757-2766. Available from: https://doi.org/10.1016/j.xphs.2020.05.022

114. Eleftheriadis G, Monou PK, Andriotis E, Mitsouli E, Moutafidou N, Markopoulou C, et al. Development and characterization of inkjet printed edible films for buccal delivery of B-complex vitamins. Pharmaceuticals. 2020;13(9):203 Pages 17.

115. Chang SY, Li SW, Kowsari K, Shetty A, Sorrells L, Nagapudi $\mathrm{K}$, et al. Binder-jet 3D printing of indomethacin-laden pharmaceutical dosage forms. J Pharm Sci. 2020;109(10):3054-3063. Available from: https://doi.org/10.1016/j.xphs.2020.06.027.

116. Kurek M, Ewelina Ł, Szafraniec J, Knapik-kowalczuk J, Paluch M, Jachowicz R. 3D printed orodispersible films with aripiprazole. Int J Pharm. 2017;533(2):413-420. Available from: https://doi.org/10.1016/j.ijpharm.2017.05.052.

117. Lamichhane S, Park J, Sohn DH, Lee S. Customized novel design of 3D printed pregabalin tablets for intra-gastric floating and controlled release using fused deposition modeling. Pharmaceutis. 2019;11(11):564. Pages 14.

118. Fina F, Goyanes A, Rowland M, Gaisford S, Basit AW. 3D printing of tunable zero-order release printlets. Polymers. 2020;12:1769. Pages 19.

119. Saydam M, Prof ST. Improving the dissolution of a waterinsoluble orphan drug through a fused deposition modelling 3dimensional printing technology approach. Eur J Pharm Sci. 2020;152:105426. Available from: https://doi.org/10.1016/ j.ejps.2020.105426.

120. Mohamed EM, Barakh Ali SF, Rahman Z, Dharani S, Ozkan $\mathrm{T}$, Kuttolamadom MA, et al. Formulation optimization of selective laser sintering 3D-printed tablets of clindamycin palmitate hydrochloride by response surface methodology. AAPS PharmSciTech. 2020;21(6):232 Page 15.

121. Healy AV, Fuenmayor E, Doran P, Geever LM, Higginbotham CL, Lyons JG. Additive manufacturing of personalized pharmaceutical dosage forms via stereolithography. Pharmaceutics. 2019;11(12):645 Pages 20.

122. Pietrzak K, Isreb A, Alhnan MA. A flexible-dose dispenser for immediate and extended release 3D printed tablets. Eur J Pharm Biopharm. 2015;96:380-387. Available from: https:// doi.org/10.1016/j.ejpb.2015.07.027.

123. Keerthi ML, Kiran RS, Rao VUM, Sannapu A, Dutt AG, Krishna KS. Evaluation aspects: a review multi unit dosage forms. Int J Pharm. 2014;28(40):214-21.

124. Gültekin HE, Tort S, Acartürk F. An effective technology for the development of immediate release solid dosage forms containing low-dose drug: fused deposition modeling 3D printing. Pharm Res. 2019;36(9):128 Pages 13.

125. Khaled SA, Alexander MR, Irvine DJ, Wildman RD, Wallace MJ, Sharpe S, et al. Extrusion 3D printing of paracetamol tablets from a single formulation with tunable release profiles through control of tablet geometry. AAPS PharmSciTech. 2018;19(8):3403-13.

126. Kyobula M, Adedeji A, Alexander MR, Saleh E, Wildman R, Ashcroft I, et al. 3D inkjet printing of tablets exploiting bespoke complex geometries for controlled and tuneable drug release. J Control Release. 2017;261:207-215. Available from: https://doi.org/10.1016/j.jconrel.2017.06.025.

127. Liu J, Tagami T, Ozeki T. Fabrication of 3D-printed fishgelatin-based polymer hydrogel patches for local delivery of pegylated liposomal doxorubicin. Mar Drugs. 2020;18(6):325 Pages 11.

128. Tsintavi E, Rekkas DM, Bettini R. Partial tablet coating by 3D printing. Int J Pharm. 2020;581:119298. Available from: https:// doi.org/10.1016/j.ijpharm.2020.119298.

129. Tagami T, Ando M, Nagata N, Goto E, Yoshimura N, Takeuchi T, et al. Fabrication of naftopidil-loaded tablets using a semisolid extrusion-type 3D printer and the characteristics of the printed hydrogel and resulting tablets. J Pharm Sci. 2019;108(2):907-913. Available from: https://doi.org/10.1016/ j.xphs.2018.08.026.
130. Khaled SA, Burley JC, Alexander MR, Yang J, Roberts CJ. $3 \mathrm{D}$ printing of tablets containing multiple drugs with defined release profiles. Int J Pharm. 2015;494(2):643-650. Available from: https://doi.org/10.1016/j.ijpharm.2015.07.067.

131. Khaled SA, Burley JC, Alexander MR, Yang J, Roberts CJ. 3D printing of five-in-one dose combination polypill with defined immediate and sustained release profiles. J Control Release. 2015;217:308-14.

132. Pereira BC, Isreb A, Forbes RT, Dores F, Habashy R, Petit JB, et al. 'Temporary Plasticiser': a novel solution to fabricate 3D printed patient-centred cardiovascular 'Polypill' architectures. Eur J Pharm Biopharm. 2019;135:94-103. Available from: https://doi.org/10.1016/j.ejpb.2018.12.009.

133. Robles-Martinez P, Xu X, Trenfield SJ, Awad A, Goyanes A, Telford R, et al. 3D printing of a multi-layered polypill containing six drugs using a novel stereolithographic method. Pharmaceutics. 2019;11(6):274 Pages 16.

134. Pereira BC, Isreb A, Isreb M, Forbes RT, Oga EF, Alhnan MA. Additive manufacturing of a point-of-care "polypill:" fabrication of concept capsules of complex geometry with bespoke release against cardiovascular disease. Adv Healthc Mater. 2020;9(13):1-12.

135. Preis M, Öblom H. 3D-printed drugs for children-are we ready yet? AAPS PharmSciTech. 2017;18(2):303-308. Available from: https://doi.org/10.1208/s12249-016-0704-y.

136. Van Riet-Nales DA, De Neef BJ, Schobben AFAM, Ferreira JA, Egberts TCG, Rademaker CMA. Acceptability of different oral formulations in infants and preschool children. Arch Dis Child. 2013;98(9):725-31.

137. Öblom H, Sjöholm E, Rautamo M, Sandler N. Towards printed pediatric medicines in hospital pharmacies: comparison of $2 \mathrm{D}$ and 3D-printed orodispersiblewarfarin films with conventional oral powders in unit dose sachets. Pharmaceutics. 2019;11(7):334 Pages 33.

138. Goyanes A, Madla CM, Umerji A, Duran Piñeiro G, Giraldez Montero JM, Lamas Diaz MJ, et al. Automated therapy preparation of isoleucine formulations using $3 \mathrm{D}$ printing for the treatment of MSUD: first single-centre, prospective, crossover study in patients. Int J Pharm. 2019;567:118497. Available from: https://doi.org/10.1016/j.ijpharm.2019.118497.

139. Karavasili C, Gkaragkounis A, Moschakis T, Ritzoulis C, Fatouros DG. Pediatric-friendly chocolate-based dosage forms for the oral administration of both hydrophilic and lipophilic drugs fabricated with extrusion-based 3D printing. Eur J Pharm Sci. 2020;147:105291. Available from: https://doi.org/ 10.1016/j.ejps.2020.105291.

140. Boateng J. Drug delivery innovations to address global health challenges for pediatric and geriatric populations (through improvements in patient compliance). J Pharm Sci. 2017;106(11):3188-3198. Available from: https://doi.org/ 10.1016/j.xphs.2017.07.009.

141. Fast $\varnothing$ MM, Genina N, Kaae S, Kälvemark Sporrong S. Perceptions, preferences and acceptability of patient designed 3D printed medicine by polypharmacy patients: a pilot study. Int J Clin Pharm. 2019;41(5):1290-1298. Available from: https://doi.org/10.1007/s11096-019-00892-6.

142. Awad A, Yao A, Trenfield SJ, Goyanes A, Gaisford S, Basit AW. 3D printed tablets (Printlets) with braille and moon patterns for visually impaired patients. Pharmaceutics. 2020;12(2):172 Page 14.

143. Goyanes A, Scarpa M, Kamlow M, Gaisford S, Basit AW, Orlu M. Patient acceptability of 3D printed medicines. Int J Pharm. 2017;530(1-2):71-78. Available from: https://doi.org/10.1016/ j.ijpharm.2017.07.064.

144. Fatouros DG. Recent advances in pharmaceutical dosage forms and devices using additive manufacturing technologies. Drug Discov Today. 2018;24(2):636-643. Available from: https://doi.org/10.1016/j.drudis.2018.11.019.

145. Tren SJ, Goyanes A, Telford R, Wilsdon D, Rowland M. 3D printed drug products: non-destructive dose verification using a rapid point-and-shoot approach. Int J Pharm. 2018;549:283-92.

146. FDA. Technical considerations for additive manufactured medical devices - guidance for industry and food and drug administration staff. 2017. Available from: https://www.fda.gov/ 
regulatory-information/search-fda-guidance-documents/technical-considerations-additive-manufactured-medical-devices.

147. Trenfield SJ, Xian Tan H, Awad A, Buanz A, Gaisford S, Basit $\mathrm{AW}$, et al. Track-and-trace: novel anti-counterfeit measures for 3D printed personalized drug products using smart material inks. Int J Pharm. 2019;567:118443.

148. Mandrycky C, Wang Z, Kim K, Kim DH. 3D bioprinting for engineering complex tissues. Biotechnol Adv. 2016;34(4):422434. Available from: https://doi.org/10.1016/ j.biotechadv.2015.12.011.

149. Markstedt K, Mantas A, Tournier I, Martínez Ávila H, Hägg D, Gatenholm P. 3D bioprinting human chondrocytes with nanocellulose-alginate bioink for cartilage tissue engineering applications. Biomacromol. 2015;16(5):1489-96.

150. Ashwin B, Abinaya B, Prasith TP, Chandran SV, Yadav LR, Vairamani M, et al. 3D-poly (lactic acid) scaffolds coated with gelatin and mucic acid for bone tissue engineering. Int $\mathrm{J}$ Biol Macromol. 2020;162:523-532. Available from: https://doi.org/ 10.1016/j.ijbiomac.2020.06.157.
151. Zhou X, Nowicki M, Sun H, Hann SY, Cui H, Esworthy T, et al. 3D bioprinting-tunable small-diameter blood vessels with biomimetic biphasic cell layers. ACS Appl Mater Interfaces. 2020;12(41):45904-15.

152. Owens CM, Marga F, Forgacs G, Heesch CM. Biofabrication and testing of a fully cellular nerve graft. Biofabrication. 2013;5(4):045007.

153. Brancho-Sanchez E. Researchers 3D-print heart from human patient's cells. 2019. Available from: https://edition.cnn.com/ 2019/04/15/health/3d-printed-heart-study/index.html

154. Malkoc V. Challenges and the future of $3 \mathrm{D}$ bioprinting. $\mathrm{J}$ Biomed Imaging Bioeng. 2018;1(3):62-3.

Publisher's Note Springer Nature remains neutral with regard to jurisdictional claims in published maps and institutional affiliations. 